\title{
Occurrence, abundance and distribution of benthic macroinvertebrates in the Nyando River catchment, Kenya
}

\author{
D. A. Abongo, S. O. Wandiga, I. O. Jumba, P. J. Van den Brink, B. B. Naziriwo,
} V. O. Madadi, G. A. Wafula, P. Nkedi-Kizza and Henrik Kylin

\section{Linköping University Post Print}

\section{Tweet}

N.B.: When citing this work, cite the original article.

This is an electronic version of an article published in:

D. A. Abongo, S. O. Wandiga, I. O. Jumba, P. J. Van den Brink, B. B. Naziriwo, V. O. Madadi, G. A. Wafula, P. Nkedi-Kizza and Henrik Kylin, Occurrence, abundance and distribution of benthic macroinvertebrates in the Nyando River catchment, Kenya, 2015, African Journal of Aquatic Science, (40), 4, 373-392.

African Journal of Aquatic Science is available online at informaworld ${ }^{\mathrm{TM}}$ :

http://dx.doi.org/10.2989/16085914.2015.1113397

Copyright: National Inquiry Services Centre (NISC) / Taylor \& Francis: STM, Behavioural Science and Public Health Titles

http://www.tandf.co.uk/journals/default.asp

Postprint available at: Linköping University Electronic Press

http://urn.kb.se/resolve?urn=urn:nbn:se:liu:diva-123840 


\title{
OCCURRENCE, ABUNDANCE AND DISTRIBUTION OF BENTHIC MACROINVERTEBRATES ALONG RIVER NYANDO DRAINAGE BASIN, KENYA
}

\author{
Abong'o $\mathrm{DA}^{1 *}$, Wandiga $\mathrm{SO}^{1}$, Jumba $\mathrm{IO}^{1}$, Van den Brink $\mathrm{PJ}^{2}$, Naziriwo $\mathrm{BB}^{3}$,Madadi $\mathrm{VO}^{1}$, \\ Wafula GA ${ }^{1}$, Nkedi-Kizza $\mathrm{P}^{4}$, Kylin $\mathrm{H}^{5,6}$ \\ 1. University of Nairobi, Department of Chemistry, Nairobi, Kenya \\ 2. Wageningen University, Aquatic Ecology and Water Quality Management Group, \\ Wageningen, The Netherlands \\ 3. Makerere University, Department of Chemistry, Kampala, Uganda \\ 4. University of Florida, Soil and Water Science Department, Gainsville, Florida, USA \\ 5. Linköping University, Departments of Thematic Studies - Environmental Change, \\ Linköping, Sweden \\ 6. North West University, Environmental Sciences and Development, Potchefstroom, South \\ Africa \\ *Corresponding author: e-mail dabongo@uonbi.ac.ke
}

\begin{abstract}
A baseline study was conducted of the occurrence of macroinvertebrates at 26 sites in the Nyando River catchment in 2005-2006. A total of 13 orders and 16 families of Arthropoda, Mollusca, Platyhelminthes and Annelida were collected, with the order Ephemeroptera being most abundant in the up- and mid-stream reaches, followed by Hemiptera and Plecoptera respectively. The downstream sections of the river were dominated by Hirudinea and tubificids, as the water quality deteriorated mainly due to local land use, raw sewage effluent discharge and annual floods. Insects and annelids were the main invertebrates found and the extent of pollution increased from mid-section (Site 15) downwards as the river flowed into the Winam Gulf. Stringent management measures are required to safeguard the environment and ecosystems of Lake Victoria.
\end{abstract}

Key words: Biodiversity index, environmental monitoring, Lake Victoria Basin, species distribution, water quality, Winam Gulf 


\section{INTRODUCTION}

Benthic macroinvertebrates differ in their sensitivity to water pollution and, therefore, provide information about the quality of a water body over a period of time (Grant 2002). The presence of fish may not provide adequate information about long-term water quality problems because fish can move away to avoid polluted water and then return when conditions improve. Most benthic macroinvertebrates cannot move far enough to avoid pollution and the biodiversity of macroinvertebrates can, therefore, provide information about pollution that may not be present at the time of sample collection (Grant 2002).

Although water quality has a strong impact on biological components in aquatic systems (Grant 2002; Ndaruga et al. 2004), the literature on macroinvertebrate composition, distribution and diversity in East Africa is limited (Mwangi 2000; Kilonzo et al. 2014). Only a few studies have attempted to relate macroinvertebrate composition, density, diversity or assemblage to the aquatic environmental conditions (Ndaruga et al. 2004; Masese et al. 2009; Raburu et al. 2009; Mbaka et al. 2014). Typically, these studies focused on biodiversity in relation to different pollution levels, although this aspect was not investigated in depth. The use of macroinvertebrate sensitivity for environmental assessment and monitoring of the water quality of streams and rivers is, consequently, still uncommon in most of Africa. The exception is South Africa, where a scoring system for rapid bioassessment of river water quality has been used in the national biomonitoring programme (Dallas 1997; Dickens and Graham 2002).

The structure, taxonomic composition and temporal distribution of benthic macroinvertebrates in the Nyamweru River, Uganda, were surveyed by Tumiwesigye et al. (2000). Mathooko (2002) investigated colonisation of artificial substrates by aquatic insects in the Naro-Moru River, Kenya, and 10 orders of macroinvertebrates, dominated by Ephemeroptera, Trichoptera and Diptera, were found in streams of the Lake Naivasha catchment (Barnard and Biggs 1988). Only a few oligochaetes and chironomids were found in the anoxic section of the Nairobi River, while Trichoptera and Simuliidae were present at the Nairobi Falls and the upper reaches of the river (Kinyua and Pacini 1991). Ndaruga et al. (2004) studied the impacts of water quality parameters on macroinvertebrate assemblages in the Gatharaini River basin, Central Kenya. There have also been attempts to develop a biodiversity index for a river system emptying into the Kenyan sector of Lake Victoria (Masese et al. 2009; Raburu et al. 2009). Raburu et al. (2009) reported 13 orders in both the Nyando and Kipkarren rivers, and 15 in the Moiben River in the upper catchment of the Lake Victoria basin in Kenya.

In East Africa, the water quality of Lake Victoria is considered especially problematic (LVEMP 1999). It is important to study and understand the water quality and pollutants of the rivers of the Lake Victoria catchment to determine the types of action required to improve the water quality of the lake. The Nyando River is one of the most important rivers feeding into the Kenyan sector of Lake Victoria (LVEMP 2003). Therefore the aim of the present study was to assess the occurrence, abundance and distribution of benthic macroinvertebrates in the Nyando River basin, to correlate these to the impacts of measured physical and chemical parameters, and to establish baseline data for the river from which future changes in 
water quality could be evaluated. The long-term goal was to develop a scoring system to assess the water quality and pollution status of other river basins in the Lake Victoria catchment and elsewhere in East Africa.

\section{MATERIALS AND METHODS}

\section{The Study Area}

The Nyando River (Figure 1) has a total length of $170 \mathrm{~km}$ and a catchment area of $3450 \mathrm{~km} 2$ which lies between $0^{\circ} 25^{\prime} \mathrm{S}$ and $0^{\circ} 10^{\prime} \mathrm{N}$ and between $34^{\circ} 50^{\prime} \mathrm{W}$ and $35^{\circ} 50^{\prime} \mathrm{E}$. The climate is subhumid with a mean annual temperature of $23{ }^{\circ} \mathrm{C}$. The mean annual rainfall of $1360 \mathrm{~mm}$ varies from $1000 \mathrm{~mm}$ near Lake Victoria to over $1600 \mathrm{~mm}$ in the highlands (NES 2002). The annual rainfall is bimodal with peaks during the long rains (March-May) and short rains (October-December). The rainfall depends on the north-south movements of the InterTropical Convergence Zone (ITCZ) during the dry seasons (January-February) (NES 2002).

The Nyando River has two main tributaries, the small Nyando River (Kericho-Upper Nyando) and the Ainamotua River (Nandi-Lower Nyando). The Awach-Kano River flows into the main Nyando River 15 km downstream of the small Nyando-Ainamotua confluence. The Nyando Basin drains major agricultural and industrial zones of eastern Kenya. The average annual and monthly runoff flows are $18.0 \mathrm{~m}^{3} \mathrm{~s}^{-1}$ and $18.3 \mathrm{~m}^{3} \mathrm{~s}^{-1}$, respectively (LVEMP 2003). The Nyando River has the highest average sediment transport capacity index (0.30) and average slope (5\%) of all rivers draining into Lake Victoria (LVEMP 2003).

\section{Environmental conditions at sampling sites}

Small-scale subsistence maize, sorghum and rice farming characterise the lower part of the watershed and the lake plains. At higher altitudes, there are large- and small-scale maize farms, sugarcane and coffee plantations, tea estates and small-scale horticulture. There are severe widespread land degradation problems throughout the Nyando River basin that affect an estimated $1444-1932 \mathrm{~km}^{2}$ of its area (Odada et al. 2009). These include accelerated runoff and sheet erosion over much of the basin leading to severe rill, gully and stream bank erosion in the lower parts of the river basin, as well as landslides in the upper parts. The principal causes of erosion in the basin include deforestation of the headwaters and slash-andburn agricultural activities over extensive areas of fragile lands on both hill slopes and plains, coupled with loss of watershed-filtering functions through encroachment on the wetlands and loss of riverine vegetation (Abong'o 2009).

Two areas of the Nyando River basin were investigated: the Kericho-Upper Nyando and Nandi-Lower Nyando subbasins. Twenty-six sampling sites were identified by the Lake Victoria Environment Management Project (LVEMP) Pollution Loading Component in Kenya (Figure 1): Sites 1-14 in the Kericho-Upper Nyando sub-basin and Sites 15-33 in the Nandi-Lower Nyando basin (Table 1). The sampling sites were selected based on the levels of human interference (low vs high human impact) and water quality. Sites were considered as "reference" if the streams were in the forest and had no human settlements or activities within $1 \mathrm{~km}$ upstream, and if the riparian vegetation was intact. "Impaired" sites were 
identified as those with damaged or eroded riverbanks and no human activities within the 10m riparian zone, such as manmade erosion, sand mining, recreation, and point or non-point sources of pollution like industries and municipal discharges into the river within $15 \mathrm{~km}$ upstream. Other sites were classified as "moderately impaired".

Benthic macroinvertebrates and water samples were collected from the sampling sites representative of the Nyando River drainage basin. The sampling was done four times a year, in February, May, September and December 2005, and in similar periods in 2006, to capture the effects of different seasons and human activities on the benthic macroinvertebrates. Typically, May and February are the wettest and driest months, respectively.

\section{Macroinvertebrate sampling and identification}

Benthic macroinvertebrate samples were collected using a $500-\mu \mathrm{m}$ mesh kick-net for 1 minute in an area measuring approximately $1 \mathrm{~m}^{2}$ (Grant 2002). Sieves of 500- $\mu \mathrm{m}$ mesh size were used to separate organisms from sediments. Large debris was removed from the samples after carefully washing off the attached organisms into a bucket and the water filtered through $250-\mu \mathrm{m}$ mesh size sieves after hand sorting to separate the organisms from debris. Samples were taken randomly over a river length of $50 \mathrm{~m}$ at each site, put in labelled 750-ml amber bottles and preserved in 10\% formalin. Samples from all the sites were taken to the Zoology Department laboratory at the University of Nairobi for counting and identification. In the laboratory, samples were filtered through $250-\mu \mathrm{m}$ mesh sieves, rinsed with distilled water into Petri dishes and sorted, identified and counted under a stereomicroscope to the lowest possible taxonomic level using identification keys by Quigley (1977) and Merritt and Cummins (1996), and preserved in 70\% alcohol.

\section{Measurements of water quality parameters and river flow}

Temperature, $\mathrm{pH}$, conductivity and dissolved oxygen (DO) were measured in the field at depths of about 5-10 cm below the water surface at the time of macroinvertebrate sample collection using a precalibrated Hydrolab YSI 610 instrument. River width and water depth were measured using a tape measure and a graduated rod, respectively. Current velocity was measured at $60 \%$ of the total water depth with a 2030R flow meter (General Oceanics, Florida). Whenever cross-sectional area measurements could not be made due to high flows, a rough estimate of velocity was made by measuring the time required for a weighted float to travel a fixed distance along the river (Grant 2002). Water discharge was calculated from velocity, width and depth data, as described by Gordon et al. (2004).

The water for physical and chemical analysis was collected from each sampling site using three 1-litre plastic containers, thoroughly cleaned by rinsing with nitric acid (8 $\mathrm{M}$ $\mathrm{HNO}_{3}$ ), followed by repeated washing with de-ionised water and thrice rinsed with sample water before collection. Samples were placed in cooler boxes and taken to the LVEMP laboratory in Kisumu, stored in freezers at $-18{ }^{\circ} \mathrm{C}$ prior to the determination of turbidity, total nitrogen (TN), phosphorus (TP) and suspended solids (TSS). For the determination of TN, TP and TSS, the method of Mackereth et al. (1989) was used. 


\section{Data Analysis}

The collected macroinvertebrates were analysed to obtain average number of organisms per square metre $\left(\mathrm{m}^{-2}\right)$ and the percentage composition of each taxonomic group in the two subcatchments. The data were presented in terms of differences in faunal occurrence (order and families) and the required information on composition, diversity, densities and distribution of macroinvertebrates in the two subcatchments were obtained. Diversity indices were calculated using the Shannon-Wiener function $\left(H^{\prime}\right)$ (Shannon 1948).

The data were analysed using CANOCO for Windows Version 5 (ter Braak and Šmilauer 2012). All analyses were performed for each catchment separately. The first analysis was performed to show the changes of the were introduced as species and sampling date as nominal explanatory variables. A permutation test was performed under the canonical correspondence analysis (CCA) option, since the lengths of gradients were rather large (>3.5 $\mathrm{SD})$.

For the second analysis, the CCA option was also used to test significance of the fraction of variance in the community composition of the macroinvertebrates that is explained by all physico-chemical parameters separately. In these tests sampling date was introduced as covariables, the biological dataset as species, and the physico-chemical dataset as explanatory variables. From this analysis a graphical overview of the differences in species composition between the sites and their correlations with the measured explanatory variables was obtained.

\section{RESULTS}

\section{Site categories and environmental conditions}

Due to the scarcity of previous data from the region, the selected sites were classified as reference, impaired and moderately impaired sites. The Nyando River had one reference site at the upper reaches (Site 30), and 12 impaired and 13 moderately impaired sites in the mid and lower sections. Human and industrial activities were concentrated in the middle and lower reaches (Table 1). The highest densities, abundance and distribution of macroinvertebrates are presented in Table 2, i.e. for May 2005 and 2006 in the upper subcatchment, and for February 2005 and 2006 in the lower subcatchment. The physicochemical parameters for the corresponding periods in the two subcatchments are presented in Table 3. Appendices 1 and 2 contain additional information on the taxa and physicochemical parameters found at the various sampling sites during all four sampling seasons, 2005 and 2006.

\section{Macroinvertebrate assemblage characteristics}

A total of 13 orders and 16 families were recorded from each of the two subcatchments. The benthic macroinvertebrates collected were dominated by the Arthropoda, which were mainly larvae, nymphs and pupae of Hemiptera (Belostomatidae), Ephemeroptera (Baetidae, Caenidae), Plecoptera (Perlidae), Trichoptera (Limnephilidae), Neuroptera (Sisyridae), 
Zygoptera, Anisoptera, Coleoptera (Elmidae, Psephenidae) and Diptera (Athericidae, Culicidae). Hydrachnidae, Naididae (Tubificidae) and Hirudinea were also present.

\section{Density, abundance and distribution}

The density (individuals per m2) and distribution of macroinvertebrate families per sampling sites in the two subcatchment areas were recorded. Detailed data are presented in Table 2 and Appendix 1. In the Kericho subcatchment, Site 1 had the highest densities of 478 ind. $\mathrm{m}^{-2}$ and 484 ind. $\mathrm{m}^{-2}$ in the two sampling years, respectively (Table 2). This was followed by Site 6 with 447 ind. $\mathrm{m}^{-2}$ and 425 ind. $\mathrm{m}^{-2}$, respectively. At Site 1 the order Ephemeroptera had the highest density followed by the Plecoptera. These were mainly nymphs of Baetidae (188 ind. $\mathrm{m}^{-2}, 195$ ind. $\mathrm{m}^{-2}$ ), Caenidae (49 ind. $\mathrm{m}^{-2}, 30$ ind. $\mathrm{m}^{-2}$ ) and Hydrachnoidea (36 ind. $\mathrm{m}^{-2}, 47$ ind. $\mathrm{m}^{-2}$ ) in 2005 and 2006, respectively. The order Ephemeroptera dominated the taxonomic composition, contributing 74\% and 68\% of total macroinvertebrates found at Site 10 in 2005 and 2006 respectively. This was followed by Trichoptera (20\% and 25\%) at Site 8 and Plecoptera (16\% and 18\%) at Site 9, respectively. The subclass Hirudinea were the only macroinvertebrate organisms not found in the Kericho-Upper Nyando area. The order Neuroptera was only found at Site 5 and contributed 3\% and 2\% of the total macroinvertebrate numbers at that site during the sampling periods, respectively. Site 4 did not have Ephemeroptera or Plecoptera in the sampling periods.

In the Nandi-Lower Nyando subcatchment area, Site 25 had the highest densities of 494 ind. $\mathrm{m}^{-2}$ and 316 ind. $\mathrm{m}^{-2}$ in the two years respectively followed by Site 33 which had densities of 331 ind. $\mathrm{m}^{-2}$ and 309 ind. $\mathrm{m}^{-2}$ respectively (Table 2). At these two sites, the dominant orders were Ephemeroptera (Baetidae, 99 ind. $\mathrm{m}^{-2}$ and 90 ind. $\mathrm{m}^{-2}$ ) and Hirudinea (159 ind. $\mathrm{m}^{-2}$ and 158 ind. $\mathrm{m}^{-2}$ ) respectively. Mollusca (Corbiculidae, 1 ind. $\mathrm{m}^{-2}$ ) and Tubificidae (7 ind. $\mathrm{m}^{-2}$ ) were the only macroinvertebrates found at Site 16 in 2005 but were absent in 2006. There were no macroinvertebrates collected from Site 17 during the same periods. Tubificidae and Hirudinea were the main invertebrates found at Sites 18 and 33. The order Ephemeroptera also dominated the taxonomic diversity (71\% and 68\%) at Site 15 in the Nandi-Lower Nyando in the sampling periods. Site 18 had the highest number of Hirudinea, contributing to $83 \%$ and $73 \%$ in 2005 and 2006, respectively, while the numbers of Tubificidae were highest at Site 16 (88\% and 76\%). The order Neuroptera was only found at Site 21 contributing $0.3 \%$ and $0.7 \%$ of the total organisms at that site in the two sampling periods.

In the Nyando River, no single family of the benthic macroinvertebrates organisms was represented at all sampled sites during the sampling periods. The Kericho- Upper Nyando had the highest density of macroinvertebrate families and the orders Hemiptera, Coleoptera and superfamily Hydrachnoidea were present at all the sampling sites but were absent in some sites in Nandi-Lower Nyando subcatchment.

There were no pollution-sensitive macroinvertebrates collected beyond Site 15 (Nyando at Ogilo). The orders Ephemeroptera, Hemiptera, Plecoptera and Trichoptera were mostly found in the upper and middle sections of the river. Tubificidae were found both at Site 4 in 
the upper section and in the lower sections of the river while Hirudinea were mainly restricted to the lower reaches at Sites 18 and 33.

\section{Biodiversity}

Sites 1 and 14 had the highest family diversity, 14 and 13 respectively, followed by Site 6 which had a diversity of 12 families while Site 4 had the lowest family diversity (Figure 2a). The Shannon-Wiener diversity index $\left(H^{\prime}\right)$ for the Kericho-Upper was 2.2244 and 1.9636 in 2005 and 2006 respectively.

In the Nandi-Lower Nyando subcatchment Site 27 showed the highest taxa diversity (13) followed by Sites 23 and 25 with diversities of 13 and 12 families each (Figure 2b). These three sites were in the upper reaches of the river. Sites 16, 17, 18 and 33 in the lower reaches had the lowest diversity ranging from 0 to 5 in 2005 and from 0 to 7 in 2006 (Figure 2b). The Shannon-Wiener index $\left(H^{\prime}\right)$ was 2.0015 and 2.0171 in 2005 and 2006 respectively. This shows higher diversity for the Kericho-Upper Nyando subcatchment than for the NandiLower Nyando.

Using CCA options to test the significance of community composition between the two subcatchments, the ordination test resulted in a $p \leq 0.001$. Sampling date explained a significant $18 \%$ of the total variation in macroinvertebrate community composition, and subcatchment explained 5\%. The datasets were therefore analysed separately for the changes in macroinvertebrate community composition in time (Table 2, Appendix 1), and for the correlation of these changes with the measured physico-chemical parameters (Table 3, Appendix 2). The analysis showed interannual variation in community composition, with the highest biodiversity in the February samples in the two subcatchments, respectively, and small intra-annual variation between the two periods. In Figure 3a, sampling date explained $19 \%$ of the total variation, of which $56 \%$ is displayed on the horizontal axis and $23 \%$ on the vertical axis. In Figure 3b, sampling date explained 15\% of the total variation, of which 59\% is displayed on the horizontal axis, while another $31 \%$ is displayed on the vertical one.

For the canonical correspondence analysis indicating the variation in macroinvertebrate community composition in relation to the physico-chemical parameters in the Kericho-Upper Nyando (Figure 4a), sampling date explained 19\% of the total variation, which is excluded from the analysis. The physico-chemical parameters explained $19 \%$ of the total variation of which $30 \%$ is displayed on the horizontal axis, while another $24 \%$ is displayed on the vertical axis. The underlined physico-chemical parameters explained a significant $(p<0.05)$ part of the variance in the community composition of the macroinvertebrates in the permutation tests, only altitude explained a significant fraction of the variance in the community composition of the macroinvertebrates of the Kericho-Upper Nyando subcatchment. Altitude was negatively associated with a higher biodiversity (Figure 4a). In contrast to the KerichoUpper Nyando subcatchment (Figure 4a), the physico-chemical parameters explained a significant part of the variance in the community composition of the macroinvertebrates in the Nandi-Lower Nyando subcatchment (Figure 4b). The physico-chemical parameters explained $15 \%$ of the total variation, of which $59 \%$ was displayed on the horizontal axis, while another $31 \%$ is displayed on the vertical axis. The underlined physico-chemical 
parameters explained a significant part $(p<0.05)$ of the variance in the community composition of the macroinvertebrates in the Nandi-Lower Nyando catchment (Figure 4b). Altitude and dissolved oxygen (DO) were correlated positively, while temperatures, discharge, river width, area, TP, TSS and turbidity correlate negatively with biodiversity (Figure 4b).

\section{DISCUSSION}

The number of macroinvertebrate orders found in this study is higher than in other studies from Kenya, except that of Mbaka et al. (2014). A total of 13 orders were identified in this study as compared to 10 found in the Lake Naivasha catchment streams (Barnard and Biggs 1988) and eight in the Sagana River (Mwangi 2000). In the anoxic section of the Nairobi River only a few individual Oligochaeta and Chironomidae were found (Kinyua and Pacini 1991). Only two dipteran families were found in the present study as compared to three reported in Lake Naivasha catchment streams (Barnard and Biggs 1988) and six in the Gatharaini River (Ndaruga et al. 2004). Specifically for the Nyando River catchment 13 orders and 65 families were found at five sites (Raburu et al. 2009) as compared to 13 orders and 16 families in this study. However, the higher number of families found by Raburu et al. (2009) is attributed to a single sampling site, inhabited by hippopotamus, located within the wetland at the river mouth in Winam Gulf. This site was excluded from the present study.

In the Kericho-Upper Nyando catchment, Sites 1 and 14 (moderately impaired) had the highest taxon diversity, while Sites 4, 7 and 8 (impaired) had the lowest (Figure 2a). This may be attributed to pollution at those sites. Site 4 receives raw domestic sewage directly from Londiani township while Sites 7 and 8 receive runoff laden with agrochemicals from maize, cabbage, kale, and potato farms in Kipkelion Division (Abong’o 2009).

In the Nandi-Lower Nyando subcatchment, Sites 23, 25 and 27 (moderately impaired) showed the highest diversity of taxa (Figure 2b). Sites 16, 17, 18 and 33 (impaired) in the lower reaches of the Nyando River are prone to severe annual floods, and hence had the lowest taxon diversity (Abong’o 2009). Site 17 receives raw domestic sewage effluent from Ahero township while Sites 18 and 33 are served with water from channels in the irrigated rice growing areas in Ahero where agrochemicals are intensively used (Abong'o et al. 2014). The Kericho-Upper Nyando subcatchment had higher taxon diversity than the Nandi-Lower Nyando section. The taxon diversity decreased downstream with no benthic macroinvertebrates caught at Site 17, the most downstream site in either 2005 or 2006. The abundance of most macroinvertebrates declined downstream of Site 15. Tubificidae and Hirudinea were the main invertebrates found beyond this sampling site. The Oligochaeta are tolerant to pollution (Ndaruga et al. 2004). This implies that the stress imposed by pollution is highest beyond sampling Site 15 on the Nyando River, and that it increases in the downstream sections as the river drains into the Winam Gulf (Abong'o 2009). Altitude was the major determinant for the macroinvertebrate community composition in the KerichoUpper Nyando subcatchment (Figure 4a). Most macroinvertebrates were found in the middle section of the river, which comprised the moderately impaired Sites 5, 6, 9, 10, 11, 12 and 14. 
Site 13 (impaired) had very few macroinvertebrates, as it receives discharges from a calcium carbonate factory as well as runoff from nearby sugarcane farms.

In the Nandi-Lower Nyando subcatchment, altitude and DO showed a strong positive correlation with the macroinvertebrate community composition (Figure 4b). Most macroinvertebrate families were found in the upper reaches of the river at higher altitude with very close proximity to Nandi Hills, which receives rainfall almost throughout the year (Abong'o 2009). This study indicates that the temperatures in the Nandi-Lower Nyando section are lower (Table 3). Oxygen dissolves more easily in cold than in warm water (Grant 2002). Low water temperatures, therefore, favour increased DO and, hence, indirectly the survival of macroinvertebrate (Grant 2002).

Higher discharge (flow rate), large surface area and river width had negative correlations to the macroinvertebrate assemblage. River discharge, area and width have a profound effect on the composition of a riverbed (sand or silt) and prevent the benthic invertebrates from maintaining a foothold, respiring and feeding (Grant 2002). As the amount of water in a river increases, the river must adjust its velocity and cross sectional area in order to form a balance. Discharge increases as more water is added through rainfall, from tributaries, or from groundwater seeping into the river. As discharge increases, generally width, depth and velocity of the river also increase. Increasing the depth and width of the stream may cause the stream to overflow its channel resulting in a flood. Floods occur when the discharge of the stream becomes too high to be accommodated within the normal river channel. Flooded rivers are often responsible for heavy sand and silt transportation and deposition downstream (LVEMP 2003). Variable flow rate can have a far greater impact on benthic populations than low levels of pesticide contamination (Grant 2002). High turbidity is linked to high amounts of total suspended solids (TSS) that affect the macroinvertebrate composition in water. Macroinvertebrates attach strongly to suspended particulate matter and will be transported downstream fairly quickly. Increases in TP, turbidity, TSS, area, width and discharge showed strong negative correlations with macroinvertebrate population distribution (Figure 4b); however, TP has little direct impact on fauna (Grant 2002). Therefore turbidity, TSS, area, width and discharge determine much of the population distribution in the Nandi-Lower Nyando subcatchment.

In the Nyando River drainage catchment, the order Ephemeroptera was the most abundant taxon, followed by Hemiptera, Plecoptera and Trichoptera respectively and was mainly found in the upper and middle reaches of the river. Hirudinea and Tubificidae were mainly found in the lower sections of the river where phosphates and nitrate fertilisers are intensively used in the irrigated rice farms (Abong'o et al. 2014). Human activities at the downstream sites may have a negative effect on the diversity of in-stream habitats through trampling and sedimentation, as well as on macroinvertebrate assemblages. An increase in the intensity of cattle grazing (Braccia and Voshell 2007) has been reported to affect sensitive macroinvertebrate taxa and in-stream habitats negatively (McInnis and McIver 2009). 


\section{Conclusion}

This study has established baseline data regarding the occurrence, abundance and distribution of benthic macroinvertebrates in the Nyando River catchment, which can be used to evaluate the current and future biodiversity and river water quality. Both point and non-point sources of pollution have been identified. Pollution problems are severe from Site 15 downstream as the river flows into Winam Gulf. Better management of the Nyando River catchment is required before it reaches the point of no return in terms of environmental conservation. The results of this study can form the basis for the study of the other waterways of Lake Victoria and that of the lake itself.

The benthic macroinvertebrate communities responded to changes in water quality (Abong'o 2009) and this was seen in changes in the composition of family assemblages, and in diversity and densities along the river. Improper land-use practices, such as overuse of extensive areas of fragile lands, both on the hill slopes and in the plains, for subsistence and plantation agriculture, industrial pollution from a calcium carbonate factory, and raw sewage effluent from municipalities, negatively influence the environmental conditions in the Nyando River.

Currently, there are no mitigation measures in place to reverse or contain disturbances. There is need for the National Environmental Management Authority (NEMA) in Kenya to prohibit the disposal of raw industrial and sewage effluents into lakes and rivers by enforcing existing and new environmental legislations. Cultivation of river channels and riparian lands, as well as the reclamation of wetlands and the clearing of forest cover for human settlements, should be prohibited to minimise negative effects on water resources and biodiversity. Cleared marshy and swampy areas along the rivers should be restored and protected in future during the implementation of development projects.

In the meantime, urban councils, together with other relevant government ministries, should control unacceptable land-use and development plans on riparian land. Future development plans for residential and industrial areas should cater for proper sanitation and solid waste disposal systems. There is also a need to carry out similar studies for the other waterways feeding Lake Victoria.

Acknowledgements - We are grateful to the International Foundation for Science (IFS), which provided the research grant (No.W3982-1) for this project. The Higher Education Loans Board (HELB) in Kenya for the partial sponsorship during this study. Mr. John Okungu, Project Manager, Lake Victoria Environment Management Project, Kisumu, Kenya, who provided a vehicle and field officers for sample collection.

\section{References}

Abong'o DA. 2009. Occurrence, distribution and environmental impact of organochlorine pesticide residues in the Lake Victoria catchment: a case study of River Nyando drainage basin of Winam Gulf in Kenya. PhD thesis, University of Nairobi, Kenya.

Abong'o DA, Wandiga SO, Jumba IO, Madadi VO, Kylin H. 2014. Impacts of pesticides on human health and environment in the River Nyando catchment, Kenya. International Journal of Humanities, Arts, Medicine and Sciences 2: 1-14.

Barnard PC, Biggs J. 1988. Aquatic macroinvertebrates in Lake Naivasha catchment streams. Revue d'Hydrobiologie Tropicale 21: 127-134. 
Braccia A, Voshell JR Jr. 2007. Benthic macroinvertebrate responses to increasing levels of cattle grazing in Blue Ridge Mountain streams, Virginia, USA. Environmental Monitoring and Assessment 131: 185-200.

Dallas HP. 1997. A preliminary evaluation of aspects of SASS (South Africa Scoring System) for the rapid bioassessment of water quality in rivers, with particular reference to the incorporation of SASS in a national biomonitoring programs. Southern African Journal of Aquatic Sciences 23: 79-94.

Dickens CWS, Graham PM. 2002. The South African Scoring System (SASS) Version 5 rapid bioassessment method for rivers. African Journal of Aquatic Science 27: 1-10.

Gordon ND, McMahon TA, Finlayson BL, Gippel CJ, Nathan RJ. 2004. Stream hydrology: an introduction for ecologists. Chichester: John Wiley \& Sons.

Grant FI. 2002. Environmental parameters. In: Grant IF, Tingle CCD (eds), Ecological monitoring methods for the assessment of pesticide impact in the tropics. Chatham: Natural Resources Institute. pp 115-157.

Kilonzo F, Masese FO, Van Griensven A, Bauwens W, Obando J. 2014. Spatial-temporal variability in water quality and macro-invertebrate assemblage in the Upper Mara River basin, Kenya. Physics and Chemistry of the Earth 67-69: 93-104.

Kinyua AM, Pacini N. 1991. The impact of pollution on the ecology of the Nairobi-Athi River system in Kenya. International Journal of BioChemiPhysics 1: 5-7.

LVEMP (Lake Victoria Environmental Management Project). 1999. Environmental, technical socio-economic, gender and socio-cultural issues in catchment conservation: main findings and conclusions. Interim Report. Diversified Management Dynamics Ltd, Nairobi.

LVEMP (Lake Victoria Environmental Management Project). 2003. Phase 1, Revised draft: scientific stocking report-progress during LVEMP 1 and challenges for the future. World Bank, Washington, DC.

Mackerth FJH, Heron J, Talling JF. 1989. Water analysis; some revised methods for limnologists (2nd edn). FBA Scientific Publication No. 36. Ambleside, Cumbria: Freshwater Biological Association.

Masese FO, Raburu PO, Muchiri M. 2009. A preliminary benthic macroinvertebrate index of biotic integrity (B-IBI) for monitoring the Moiben River, Lake Victoria Basin, Kenya. African Journal of Aquatic Science 34: 1-14.

Mathooko JM. 2002. The sizes, maturity stages and biomass of mayfly assemblages colonising disturbed streambed patches in central Kenya. African Journal of Ecology 40: 84-93.

Mbaka JG, M'Erimba CM, Thiongo HK, Mathooko JM. 2014. Water and habitat quality assessment in the Honi and Naro Moru rivers, Kenya, using benthic macroinvertebrate assemblages and qualitative habitat scores. African Journal of Aquatic Science 39: 361368.

McInnis M, McIver J. 2009. Timing of cattle grazing alters impacts on stream banks in an Oregon mountain watershed. Journal of Soil and Water Conservation 64: 394-399.

Merrit RW, Cummins KW. 1996. An introduction to the aquatic insects of North America (3rd edn). Dubuque, Iowa: Kendell/Hunt.

Mwangi BM. 2000. Bed sediments, organic matter and macroinvertebrate response to changes in catchment land use along a low order tropical stream; Sagana River, Kenya. MSc thesis, Vienna University, Austria. 
Ndaruga MA, Ndiritu GG, Gichuki NN, Wamicha WN. 2004. Impact of water quality on macro-invertebrate assemblages along a tropical stream in Kenya. African Journal of Ecology 42: 208-216.

NES (National Environment Secretariat). 2002. First national communication of Kenya to the conference of the parties to the United Nation Framework convention on climate change (UNFCCC). NES, Nairobi.

Odada EO, Ochola WO, Olago DO. 2009. Drivers of ecosystem change and their impact on human well-being in Lake Victoria basin. African Journal of Ecology 47: 46-54.

Quigley ED. 1977. Invertebrates of streams and rivers. London: Edward Arnold.

Raburu PO, Masese FO, Mulunda CA. 2009. Macro-invertebrate Index of Biotic Integrity (M-IBI) for monitoring rivers in the upper catchment of Lake Victoria Basin, Kenya. Aquatic Ecosystem Health \& Management 12: 197-205.

Shannon EP. 1948. A mathematical theory of communication. Bell System Technical Journal 27: 379-423.

ter Braak CJF, Šmilauer P. 2012. Canoco reference manual and user's guide: software for ordination, version 5.0. Ithaca: Microcomputer Power.

Tumiwesigye C, Yusuf SK, Makanga B. 2000. Structure and composition of benthic macroinvertebrates of a tropical forest stream, River Nyamweru, western Uganda. African Journal of Ecology 38: 72-77. 
Figure 1

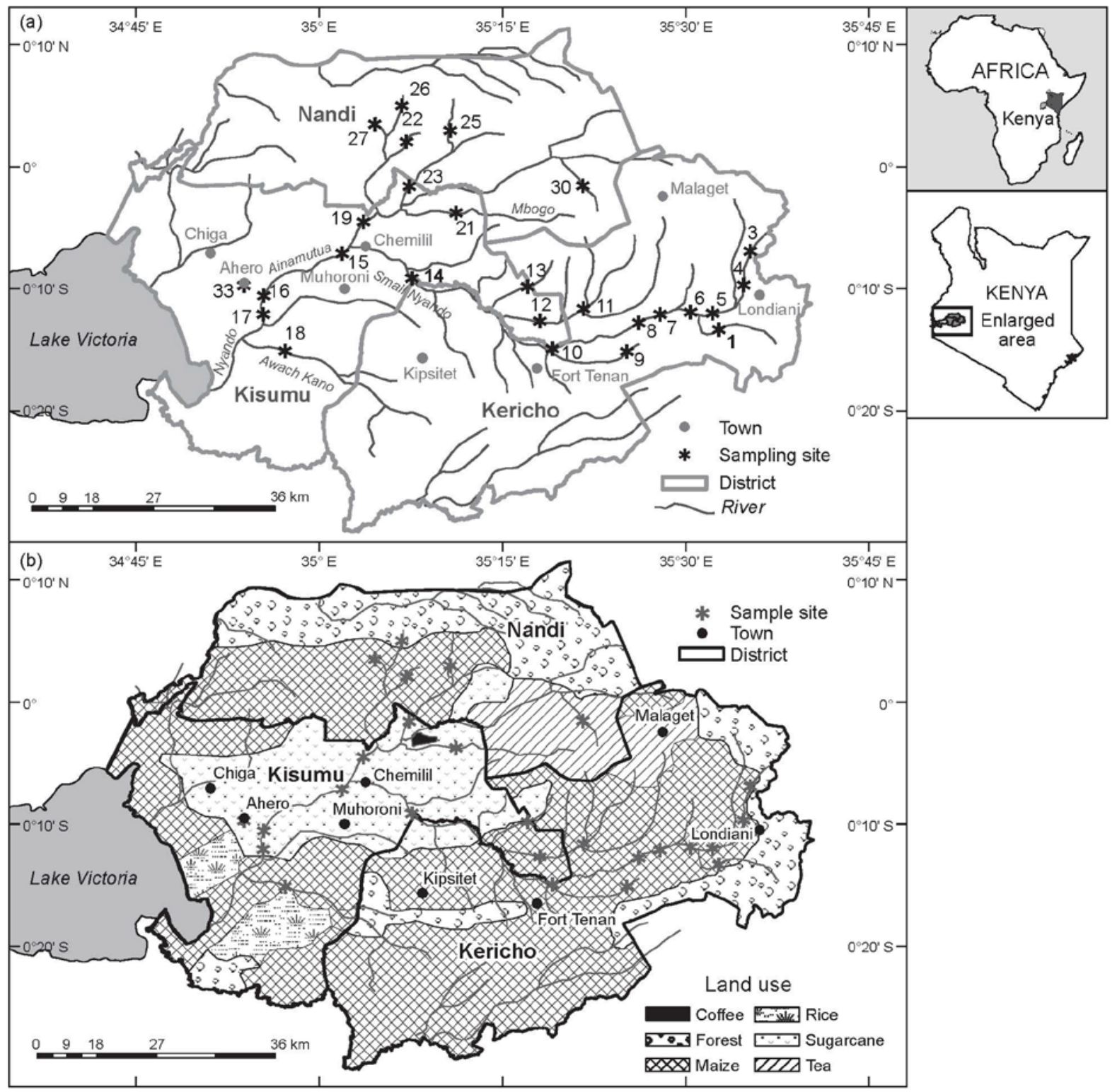

Figure 1: Map of the Nyando River drainage basin showing (a) rivers and locations of sampling sites, and (b) land use. 


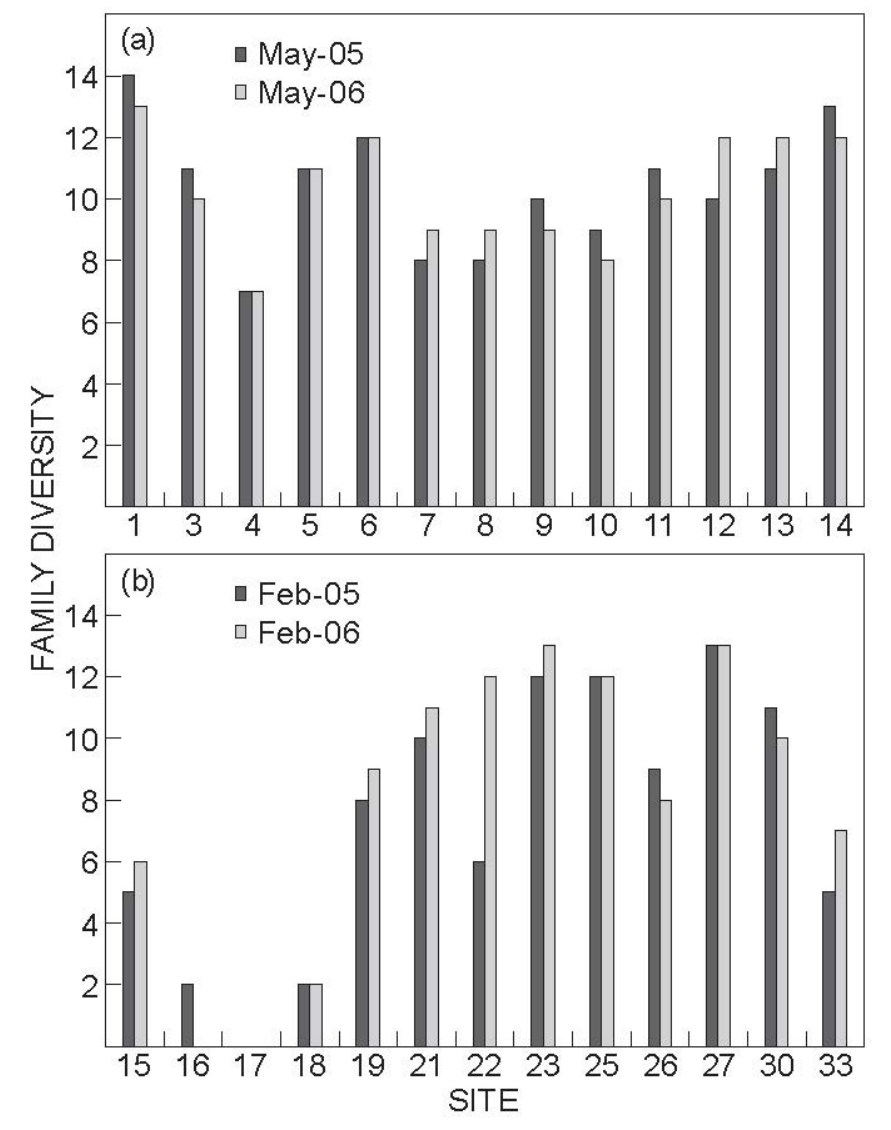

Figure 2: Macroinvertebrate diversity in (a) the Kericho-Upper Nyando subcatchment in 2005 and 2006; and (b) the Nandi-Lower Nyando subcatchment in 2005 and 2006. 


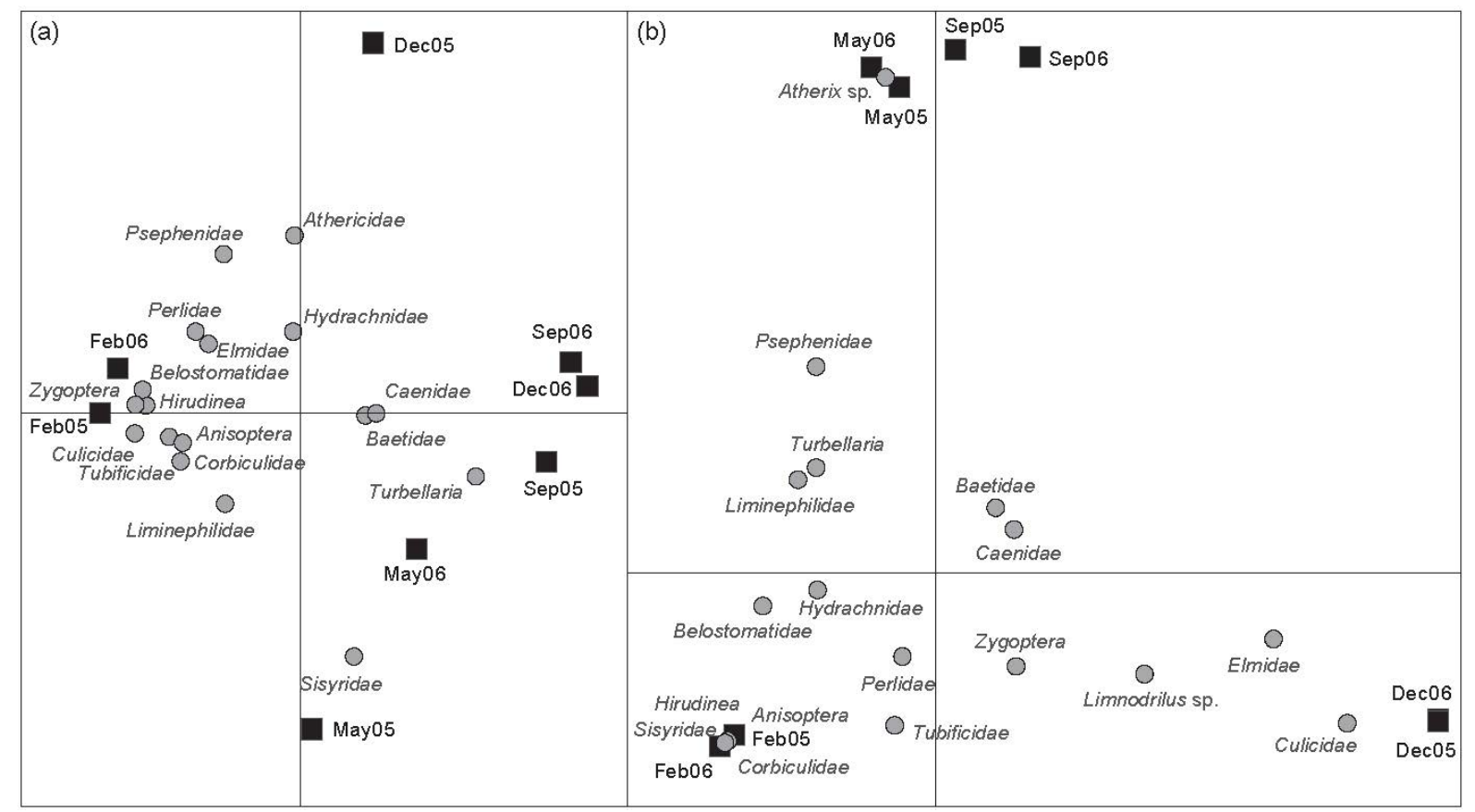

Figure 3: CCA diagram of variations in macroinvertebrate community composition in February, May, September and December 2005 and 2006 in (a) the Kericho-Upper Nyando subcatchment, and (b) the Nandi-Lower Nyando subcatchment.

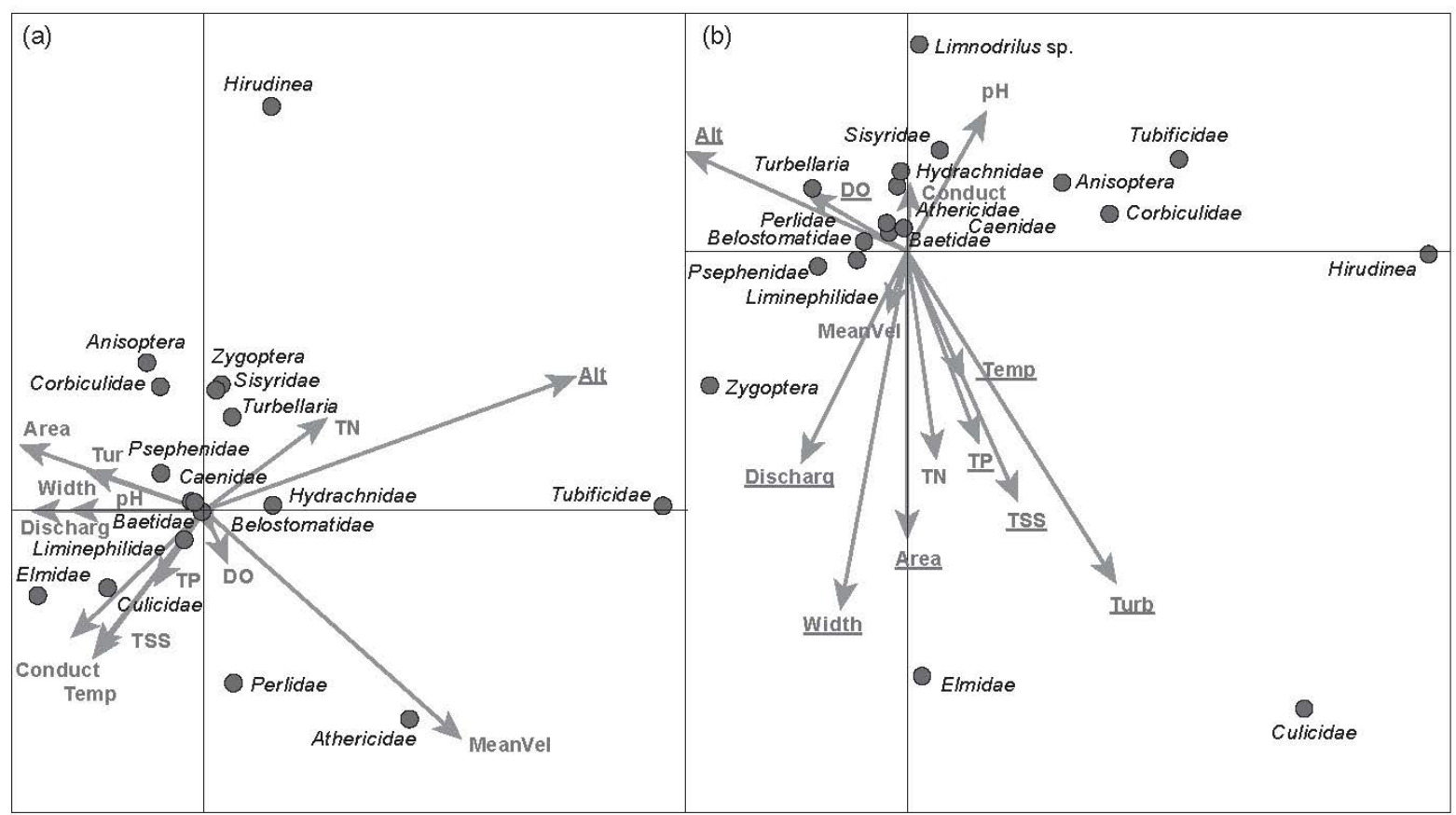

Figure 4: CCA diagram of variations in macroinvertebrate community composition in relation to the physico-chemical parameters in (a) the Kericho-Upper Nyando catchment and (b) the Nandi-Lower Nyando subcatchment. Underlined physicochemical parameters explained a significant part of the variance $(p<0.05)$ 
Table 1: Description of sampling sites in the Nyando River catchment.

\begin{tabular}{|c|c|c|c|c|c|}
\hline \multirow{2}{*}{$\begin{array}{l}\text { Site } \\
\text { no. }\end{array}$} & \multirow{2}{*}{ Name } & \multicolumn{2}{|c|}{ Coordinates } & \multirow{2}{*}{$\begin{array}{l}\text { Altitude } \\
(\mathrm{m})\end{array}$} & \multirow{2}{*}{ Human activities around sites } \\
\hline & & Latitude & Longitude & & \\
\hline \multicolumn{6}{|c|}{ Kericho-Upper Nyando subcatchment } \\
\hline 1 & Kedowa at bridge & $0.234^{\circ} \mathrm{S}$ & $35.545^{\circ} \mathrm{E}$ & 2290 & Subsistence agriculture and depleted forest cover \\
\hline 3 & Masaita at dam & $0.135^{\circ} \mathrm{S}$ & $35.602^{\circ} \mathrm{E}$ & 2310 & Subsistence agriculture and depleted forest cover \\
\hline 4 & Masaita at Londiani township & $0.163^{\circ} \mathrm{S}$ & $35.584^{\circ} \mathrm{E}$ & 2290 & $\begin{array}{l}\text { Human settlement, subsistence agriculture on river } \\
\text { banks, cattle and sheep watering, raw sewage effluent } \\
\text { discharge into the river }\end{array}$ \\
\hline 5 & Masaita at Lambel farm & $0.197^{\circ} \mathrm{S}$ & $35.536^{\circ} \mathrm{E}$ & 2050 & Cattle watering, subsistence agriculture \\
\hline 6 & Kipchorian at Tuiyobei & $0.190^{\circ} \mathrm{S}$ & $35.512^{\circ} \mathrm{E}$ & 2000 & Subsistence agriculture \\
\hline 7 & Kimoson & $0.207^{\circ} \mathrm{S}$ & $35.464^{\circ} \mathrm{E}$ & 1920 & $\begin{array}{l}\text { Subsistence agriculture on river banks, cattle and sheep } \\
\text { watering }\end{array}$ \\
\hline 8 & Nyando at Kipkelion & $0.207^{\circ} \mathrm{S}$ & $35.462^{\circ} \mathrm{E}$ & 1920 & $\begin{array}{l}\text { Subsistence agriculture on river banks, cattle watering, } \\
\text { recreation }\end{array}$ \\
\hline 9 & Tugunon at bridge & $0.250^{\circ} \mathrm{S}$ & $35.415^{\circ} \mathrm{E}$ & 2000 & Subsistence agriculture \\
\hline 10 & Namting at Fort Ternna & $0.204^{\circ} \mathrm{S}$ & $35.347^{\circ} \mathrm{E}$ & 1560 & Sugarcane farming, subsistence agriculture \\
\hline 11 & Murgut at Koru & $0.214^{\circ} \mathrm{S}$ & $35.319^{\circ} \mathrm{E}$ & 1500 & Sugarcane farming, subsistence agriculture \\
\hline 12 & Pararget at bridge & $0.212^{\circ} \mathrm{S}$ & $35.301^{\circ} \mathrm{E}$ & 1500 & Sugarcane farming, subsistence agriculture \\
\hline 13 & Homa Lime & $0.184^{\circ} \mathrm{S}$ & $35.299^{\circ} \mathrm{E}$ & 1320 & $\begin{array}{l}\text { Sugarcane farming, subsistence agriculture on river } \\
\text { banks, discharge of effluent from calcium carbonate } \\
\text { factory }\end{array}$ \\
\hline 14 & Nyando at Muhoroni bridge & $0.166^{\circ} \mathrm{S}$ & $35.184^{\circ} \mathrm{E}$ & 1280 & Sugarcane farming, subsistence agriculture on river banks \\
\hline \multicolumn{6}{|c|}{ Nandi-Lower Nyando subcatchment } \\
\hline 15 & Nyando at Ogilo & $0.166^{\circ} \mathrm{S}$ & $35.162^{\circ} \mathrm{E}$ & 1190 & Sugarcane farming, subsistence agriculture, recreation \\
\hline 16 & Nyando at Ahero bridge & $0.172^{\circ} \mathrm{S}$ & $34.921^{\circ} \mathrm{E}$ & 1170 & $\begin{array}{l}\text { Human settlement, livestock rearing, subsistence } \\
\text { agriculture, solid wastes on river banks coupled with } \\
\text { recreational activities }\end{array}$ \\
\hline 17 & Nyando at dykes & $0.201^{\circ} \mathrm{S}$ & $34.929^{\circ} \mathrm{E}$ & 1150 & $\begin{array}{l}\text { Constructed dykes, discharge raw domestic sewage from } \\
\text { Ahero town, cattle watering and recreational activities }\end{array}$ \\
\hline 18 & Awach Kano & $0.234^{\circ} \mathrm{S}$ & $34.957^{\circ} \mathrm{E}$ & 1150 & $\begin{array}{l}\text { Irrigated rice farming cattle watering coupled with } \\
\text { subsistence agriculture and recreational activities }\end{array}$ \\
\hline 19 & Ainamutua-Kibigori & $0.076^{\circ} \mathrm{S}$ & $35.056^{\circ} \mathrm{E}$ & 1210 & $\begin{array}{l}\text { Sugarcane farming, cattle watering and subsistence } \\
\text { agriculture and sand mining }\end{array}$ \\
\hline 21 & Mbogo & $0.061^{\circ} \mathrm{S}$ & $35.148^{\circ} \mathrm{E}$ & 1270 & $\begin{array}{l}\text { Sugarcane farming, subsistence agriculture on river } \\
\text { banks, recreational activities }\end{array}$ \\
\hline 22 & Anopsiwa & $0.030^{\circ} \mathrm{N}$ & $35.118^{\circ} \mathrm{E}$ & 1320 & $\begin{array}{l}\text { Large-scale sugarcane farming, sand mining and recreat- } \\
\text { ional activities }\end{array}$ \\
\hline 23 & Anopngetuny & $0.028^{\circ} \mathrm{S}$ & $35.118^{\circ} \mathrm{E}$ & 1330 & Large-scale coffee and sugarcane farming \\
\hline 25 & Chemwanabei & $0.065^{\circ} \mathrm{N}$ & $35.188^{\circ} \mathrm{E}$ & 1820 & Large-scale tea farming \\
\hline 26 & Kapngorium at bridge & $0.054^{\circ} \mathrm{N}$ & $35.100^{\circ} \mathrm{E}$ & 1850 & $\begin{array}{l}\text { Human settlement, large-scale tea farming, subsistence } \\
\text { agriculture, raw sewage effluent from tea factory }\end{array}$ \\
\hline 27 & Kundos at bridge & $0.051^{\circ} \mathrm{N}$ & $35.062^{\circ} \mathrm{E}$ & 1850 & Large-scale tea farming, subsistence agriculture \\
\hline 30 & Chebirirkut at dam & $0.037^{\circ} \mathrm{S}$ & $35.348^{\circ} \mathrm{E}$ & 1820 & Forest, no human settlement or activities \\
\hline 33 & Ahero irrigation channel & $0.172^{\circ} \mathrm{S}$ & $34.908^{\circ} \mathrm{E}$ & 1150 & $\begin{array}{l}\text { Irrigated rice farming, cattle watering and recreational } \\
\text { activities }\end{array}$ \\
\hline
\end{tabular}


Table 2: The density (individuals $\mathrm{m}^{-2}$ ) and distribution of benthic macroinvertebrates in the Nyando River catchment in 2005-2006.

\begin{tabular}{|c|c|c|c|c|c|c|c|c|c|c|c|c|c|}
\hline \multirow{2}{*}{ Taxon } & \multicolumn{13}{|c|}{ Site no. } \\
\hline & 1 & 3 & 4 & 5 & 6 & 7 & 8 & 9 & 10 & 11 & 12 & 13 & 14 \\
\hline & \multicolumn{13}{|c|}{ Kericho-Upper Nyando, May 2005} \\
\hline Turbellaria & 2 & 0 & 0 & 0 & 0 & 0 & 0 & 0 & 0 & 0 & 0 & 0 & 0 \\
\hline \multicolumn{14}{|l|}{ Oligochaeta } \\
\hline Tubificidae & 20 & 19 & 25 & 22 & 16 & 12 & 12 & 4 & 4 & 2 & 21 & 4 & 22 \\
\hline \multicolumn{14}{|l|}{ Hirudinea } \\
\hline \multicolumn{14}{|l|}{ Acariformes } \\
\hline \multicolumn{14}{|l|}{ Insecta } \\
\hline Belostomatidae & 34 & 16 & 20 & 21 & 17 & 15 & 18 & 8 & 12 & 23 & 10 & 14 & 22 \\
\hline Sisyridae & & & & 10 & & & & & & & & & \\
\hline Baetidae & 188 & 24 & & 211 & 182 & 14 & 12 & 88 & 169 & 126 & 125 & 59 & 150 \\
\hline Caenidae & 49 & 10 & & 39 & 66 & 3 & 8 & 65 & 55 & 20 & 18 & 38 & 61 \\
\hline Limnephilidae & 17 & 11 & 24 & 22 & 19 & 28 & 48 & 9 & 15 & 52 & 65 & 5 & 24 \\
\hline Perlidae & 63 & 3 & & 21 & 79 & 25 & 16 & 45 & 46 & 36 & 26 & 1 & 11 \\
\hline Zygoptera & 26 & & & & 3 & & & & 3 & 6 & & 9 & 2 \\
\hline Anisoptera & 12 & & & 10 & 6 & & & & & 1 & & 4 & 2 \\
\hline Psephenidae & 10 & 3 & 28 & & 6 & & & & & & 1 & & 5 \\
\hline Elmidae & 11 & 9 & 13 & 18 & 15 & 14 & 8 & 13 & 8 & 4 & 3 & 10 & 23 \\
\hline Culicidae & 6 & & & & & & & & & & & & 11 \\
\hline Athericidae & 1 & 23 & & & & & & 15 & & & & & \\
\hline \multicolumn{14}{|l|}{ Mollusca } \\
\hline Corbiculidae & 5 & 6 & 17 & 30 & 5 & & & 3 & & 6 & 1 & 3 & 12 \\
\hline \multirow[t]{2}{*}{ Total } & 478 & 134 & 142 & 430 & 447 & 139 & 155 & 278 & 322 & 301 & 279 & 148 & 359 \\
\hline & \multicolumn{13}{|c|}{ Kericho-Upper Nyando, May 2006} \\
\hline Turbellaria & 7 & 0 & 0 & 0 & 0 & 0 & 0 & 0 & 0 & 0 & 0 & 0 & 0 \\
\hline Oligochaeta & & & & & & & & & & & & & \\
\hline Tubificidae & 35 & & 39 & 1 & 1 & 1 & 5 & & & 6 & 6 & 1 & 17 \\
\hline Hirudinea & & & & & & & & & & & & & \\
\hline Arhynchobdellida & & & & & & & & & & & & & \\
\hline Acariformes & & & & & & & & & & & & & \\
\hline Hydrachnoidea & 47 & 72 & 61 & 34 & 62 & 29 & 27 & 36 & 6 & 16 & 11 & 3 & 13 \\
\hline Insecta & & & & & & & & & & & & & \\
\hline Belostomatidae & 54 & 2 & 22 & 11 & 8 & 1 & 6 & 9 & 7 & 15 & 17 & 10 & 8 \\
\hline Sisyridae & & & & 4 & & & & & & & & & \\
\hline Baetidae & 195 & 164 & & 131 & 125 & 107 & 46 & 94 & 139 & 78 & 61 & 81 & 173 \\
\hline Caenidae & 30 & 130 & & 93 & 88 & 67 & 23 & 72 & 99 & 60 & 44 & 60 & 111 \\
\hline Limnephilidae & & & & & & & & & & & & & \\
\hline Perlidae & & & & & & & & & & & & & \\
\hline Zygoptera & 34 & 29 & & 64 & 35 & 35 & 28 & 21 & 27 & 20 & 71 & 12 & 11 \\
\hline Anisoptera & 59 & 3 & & 9 & 70 & 3 & 10 & 38 & 19 & 12 & 13 & 4 & 18 \\
\hline Psephenidae & 4 & & 10 & & 8 & & & & & & 3 & 3 & \\
\hline Elmidae & 1 & & & 56 & 11 & & & & & 1 & 3 & 6 & 1 \\
\hline Culicidae & 3 & 29 & 27 & & 3 & 28 & & & 1 & & 8 & 2 & 1 \\
\hline Athericidae & 19 & 6 & 7 & 9 & 14 & 1 & 2 & 11 & 8 & 11 & 5 & 8 & 14 \\
\hline Mollusca & & & & & & & & & & & & & 3 \\
\hline Corbiculidae & 3 & 9 & & & & & & 9 & & & & & \\
\hline Total & 484 & 444 & 166 & 412 & 425 & 272 & 147 & 290 & 306 & 219 & 242 & 190 & 370 \\
\hline & & & & & & & Site $n$ & & & & & & \\
\hline Iaxon & 15 & 16 & 17 & 18 & 19 & 21 & 22 & 23 & 25 & 26 & 27 & 30 & 33 \\
\hline & & & & & Nar & Lowe & lyandc & ebru & 2005 & & & & \\
\hline Turbellaria & 0 & 0 & 0 & 0 & 0 & 13 & 0 & 0 & 9 & 0 & 3 & 0 & 0 \\
\hline Oligochaeta & & & & & & & & & & & & & \\
\hline Tubificidae & 3 & 7 & & 15 & 83 & & & 9 & 38 & 25 & 17 & 38 & 148 \\
\hline Hirudinea & & & & & & & & & & & & & \\
\hline Arhynchobdellida & & & & 158 & & & & 30 & & & & & 159 \\
\hline Acariformes & & & & & & & & & & & & & \\
\hline Hydrachnoidea & & & & & 7 & 41 & 8 & 34 & 45 & 14 & 18 & 21 & \\
\hline Insecta & & & & & & & & & & & & & \\
\hline Belostomatidae & 1 & & & & 15 & 42 & 21 & 14 & 47 & 17 & 35 & 9 & 2 \\
\hline Sisyridae & & & & & & 2 & & & & & & & \\
\hline Baetidae & 13 & & & & 122 & 60 & 30 & 46 & 99 & 37 & 48 & 21 & \\
\hline
\end{tabular}


Table 2: (cont.)

\begin{tabular}{|c|c|c|c|c|c|c|c|c|c|c|c|c|c|}
\hline \multirow{2}{*}{ Taxon } & \multicolumn{13}{|c|}{ Site no. } \\
\hline & 15 & 16 & 17 & 18 & 19 & 21 & 22 & 23 & 25 & 26 & 27 & 30 & 33 \\
\hline Caenidae & 8 & & & & 51 & 26 & 18 & 34 & 45 & 32 & 37 & 12 & \\
\hline Limnephilidae & 6 & & & & 18 & 35 & & 24 & 58 & 38 & 22 & 31 & \\
\hline Perlidae & & & & & 4 & 48 & & 22 & 67 & 31 & 23 & 14 & \\
\hline Zygoptera & & & & & & & & 3 & 3 & & 19 & 2 & \\
\hline Anisoptera & & & & & & & & 14 & 3 & & 7 & 7 & \\
\hline Psephenidae & & & & & & 3 & 4 & & 9 & 3 & 28 & 3 & \\
\hline Elmidae & & & & & & 10 & 13 & 32 & 56 & 23 & 16 & & 6 \\
\hline Culicidae & & & & & & & & & & & & 7 & \\
\hline Athericidae & & & & & & 8 & & 15 & & & 15 & & \\
\hline Mollusca & & & & & & & & & & & & & 3 \\
\hline Corbiculidae & & 1 & & & 21 & & & & 24 & & 1 & & 16 \\
\hline \multirow[t]{2}{*}{ Total } & 31 & 8 & 0 & 173 & 321 & 275 & 94 & 277 & 494 & 220 & 286 & 165 & 331 \\
\hline & \multicolumn{13}{|c|}{ Nandi-Lower Nyando, February 2006} \\
\hline \multicolumn{14}{|l|}{ Turbellaria } \\
\hline Tubificidae & & & & 7 & 39 & & 6 & 1 & 10 & 12 & 4 & 10 & 122 \\
\hline \multicolumn{14}{|l|}{ Hirudinea } \\
\hline Arhynchobdellida & & & & 138 & & & & 3 & & & & & 158 \\
\hline \multicolumn{14}{|l|}{ Acariformes } \\
\hline Hydrachnoidea & & & & & 4 & 18 & 13 & 13 & 15 & 12 & 11 & 28 & \\
\hline \multicolumn{14}{|l|}{ Insecta } \\
\hline Belostomatidae & 1 & & & & 15 & 42 & 21 & 14 & 47 & 17 & 35 & 9 & 2 \\
\hline Sisyridae & & & & & & 2 & & & & & & & \\
\hline Baetidae & 15 & & & & 98 & 75 & 65 & 95 & 90 & 86 & 74 & 55 & \\
\hline Caenidae & & & & & 10 & 50 & 50 & 65 & 80 & 68 & 65 & 32 & \\
\hline Limnephilidae & 2 & & & & 11 & 27 & 24 & 15 & 25 & 14 & 10 & 6 & \\
\hline Perlidae & 3 & & & & 4 & 7 & 10 & 42 & 35 & 61 & 6 & 5 & 3 \\
\hline Zygoptera & & & & & & 17 & 6 & 1 & & & 3 & 5 & \\
\hline Anisoptera & 3 & & & & & 6 & 6 & 1 & 9 & & 21 & 1 & \\
\hline Psephenidae & & & & & & & & & 4 & & 13 & & \\
\hline Elmidae & & & & & & 6 & 14 & 5 & 21 & 11 & 6 & & 2 \\
\hline Culicidae & & & & & 3 & 3 & 1 & & & & & 2 & 15 \\
\hline Athericidae & 4 & & & & & & 6 & 1 & & & 11 & & \\
\hline \multicolumn{14}{|l|}{ Mollusca } \\
\hline Corbiculidae & 6 & & & & 10 & & & 1 & 19 & & & & 10 \\
\hline Total & 27 & 0 & 0 & 145 & 187 & 219 & 210 & 268 & 316 & 300 & 229 & 154 & 309 \\
\hline
\end{tabular}


Table 3: Physical and chemical parameter values at sample sites in the Nyando River catchment in 2005-2006.

\begin{tabular}{|c|c|c|c|c|c|c|c|c|c|c|c|c|}
\hline $\begin{array}{l}\text { Site } \\
\text { no. }\end{array}$ & $\begin{array}{l}\text { Temp. } \\
\left({ }^{\circ} \mathrm{C}\right)\end{array}$ & $\begin{array}{l}\text { Conductivity } \\
\left(\mu S \mathrm{~cm}^{-1}\right)\end{array}$ & $\begin{array}{c}\text { TSS } \\
\left(\mathrm{mg} \mathrm{l}^{-1}\right)\end{array}$ & $\begin{array}{c}D O \\
\left(\mathrm{mg} \mathrm{l}^{-1}\right)\end{array}$ & $\mathrm{pH}$ & $\begin{array}{l}\text { Turbidity } \\
\text { (NTU) }\end{array}$ & $\begin{array}{c}\mathrm{TP} \\
\left(\mathrm{mg} \mathrm{l}^{-1}\right)\end{array}$ & $\begin{array}{c}\mathrm{TN} \\
\left(\mathrm{mg} \mathrm{l}^{-1}\right)\end{array}$ & $\begin{array}{l}\text { Area } \\
\left(\mathrm{m}^{2}\right)\end{array}$ & $\begin{array}{c}\text { Mean } \\
\text { velocity } \\
\left(\mathrm{m} \mathrm{s}^{-1}\right)\end{array}$ & $\begin{array}{l}\text { Discharge } \\
\left(\mathrm{m}^{3} \mathrm{~s}^{-1}\right)\end{array}$ & $\begin{array}{c}\text { River } \\
\text { width } \\
(\mathrm{m})\end{array}$ \\
\hline \multicolumn{13}{|c|}{ Kericho-Upper Nyando subcatchment, May 2005} \\
\hline 1 & 27.1 & 140 & 76 & 7.7 & 7.8 & 130 & 0.21 & 3.6 & 0.44 & 0.64 & 0.28 & 3.7 \\
\hline 3 & 28.1 & 78 & 39 & 7.0 & 7.9 & 62 & 0.08 & 3.4 & 0.34 & 0.38 & 0.13 & 2.6 \\
\hline 4 & 28.1 & 96 & 76 & 7.2 & 8.5 & 63 & 0.11 & 2.7 & 1.8 & 0.46 & 0.81 & 6.0 \\
\hline 5 & 27.7 & 110 & 63 & 8.2 & 8.7 & 80 & 0.16 & 3.8 & 4.9 & 0.43 & 2.1 & 6.2 \\
\hline 6 & 28.1 & 100 & 62 & 7.4 & 8.0 & 100 & 0.13 & 2.9 & 5.4 & 0.39 & 2.2 & 7.3 \\
\hline 7 & 27.7 & 76 & 130 & 7.2 & 7.9 & 130 & 0.15 & 2.2 & 0.88 & 0.53 & 0.45 & 2.0 \\
\hline 8 & 27.3 & 94 & 190 & 7.6 & 7.9 & 150 & 0.18 & 3.2 & 6.8 & 0.60 & 0.60 & 9.5 \\
\hline 9 & 27.3 & 81 & 170 & 7.2 & 7.8 & 130 & 0.23 & 2.7 & 1.2 & 0.56 & 0.64 & 4.5 \\
\hline 10 & 27.1 & 170 & 220 & 8.2 & 7.7 & 140 & 0.17 & 2.6 & 2.3 & 0.39 & 0.91 & 6.7 \\
\hline 11 & 27.3 & 170 & 190 & 7.5 & 8.3 & 150 & 0.23 & 1.2 & 0.42 & 0.61 & 0.26 & 2.3 \\
\hline 12 & 27.2 & 160 & 150 & 8.0 & 8.2 & 140 & 0.18 & 2.5 & 1.8 & 0.56 & 1.0 & 6.6 \\
\hline 13 & 27.2 & 170 & 65 & 8.4 & 7.9 & 56 & 0.30 & 1.9 & 2.1 & 0.34 & 0.71 & 7.5 \\
\hline 14 & 27.7 & 120 & 240 & 7.1 & 8.2 & 160 & 0.21 & 2.6 & 33.0 & 0.38 & 13.0 & 27.0 \\
\hline \multicolumn{13}{|c|}{ Kericho-Upper Nyando subcatchment, May 2006} \\
\hline 1 & 27.2 & 140 & 76 & 7.7 & 7.8 & 130 & 0.22 & 3.6 & 0.12 & 0.10 & 0.01 & 2.5 \\
\hline 3 & 28.4 & 74 & 32 & 7.0 & 7.9 & 68 & 0.08 & 3.4 & 0.29 & 0.22 & 0.06 & 0.18 \\
\hline 4 & 28.2 & 98 & 57 & 6.7 & 8.1 & 61 & 0.15 & 2.7 & 0.75 & 0.24 & 0.18 & 2.8 \\
\hline 5 & 27.1 & 119 & 69 & 8.2 & 8.0 & 79 & 0.16 & 3.8 & 1.6 & 0.21 & 0.35 & 4.2 \\
\hline 6 & 28.2 & 106 & 68 & 7.5 & 8.2 & 103 & 0.11 & 2.9 & 1.4 & 0.66 & 0.94 & 6.8 \\
\hline 7 & 27.0 & 82 & 128 & 7.2 & 8.3 & 134 & 0.15 & 2.2 & 0.39 & 0.95 & 0.37 & 2.1 \\
\hline 8 & 27.7 & 90 & 193 & 7.5 & 7.9 & 156 & 0.10 & 3.1 & 2.3 & 0.43 & 0.99 & 6.3 \\
\hline 9 & 27.5 & 86 & 173 & 7.3 & 7.8 & 137 & 0.29 & 2.7 & 1.6 & 0.68 & 1.10 & 4.0 \\
\hline 10 & 27.0 & 176 & 224 & 8.2 & 7.7 & 143 & 0.14 & 2.6 & 1.8 & 0.63 & 1.30 & 8.4 \\
\hline 11 & 27.8 & 174 & 194 & 7.5 & 8.3 & 150 & 0.22 & 1.2 & 0.6 & 0.28 & 0.18 & 3.7 \\
\hline 12 & 27.6 & 168 & 152 & 8.0 & 8.2 & 140 & 0.16 & 2.5 & 4.1 & 0.37 & 1.50 & 13.0 \\
\hline 13 & 27.8 & 170 & 68 & 8.0 & 7.9 & 59 & 0.36 & 1.9 & 1.4 & 0.38 & 0.54 & 5.4 \\
\hline 14 & 27.0 & 129 & 244 & 7.7 & 8.3 & 169 & 0.24 & 2.6 & 2.1 & 0.35 & 0.67 & 0.68 \\
\hline \multicolumn{13}{|c|}{ Nandi-Lower Nyando subcatchment, February 2005} \\
\hline 15 & 27.0 & 130 & 210 & 7.0 & 7.9 & 160 & 0.48 & 5.0 & 34 & 0.40 & 28.0 & 29.0 \\
\hline 16 & 27.4 & 130 & 330 & 7.4 & 7.6 & 260 & 0.50 & 5.0 & 28 & 1.0 & 28.0 & 29.0 \\
\hline 17 & 27.2 & 130 & 330 & 7.2 & 7.5 & 270 & 0.50 & 5.0 & 28 & 1.3 & 28.0 & 29.0 \\
\hline 18 & 26.1 & 47 & 140 & 7.7 & 7.4 & 120 & 0.23 & 5.0 & 2.8 & 0.54 & 1.6 & 6.2 \\
\hline 19 & 26.8 & 110 & 43 & 6.8 & 7.2 & 190 & 0.29 & 3.1 & 7.3 & 0.56 & 4.1 & 7.0 \\
\hline 21 & 26.9 & 110 & 210 & 6.2 & 7.4 & 190 & 0.33 & 1.4 & 2.7 & 0.64 & 1.8 & 5.0 \\
\hline 22 & 27.3 & 160 & 70 & 7.8 & 7.7 & 77 & 0.20 & 1.9 & 5.1 & 0.65 & 3.3 & 9.3 \\
\hline 23 & 27.1 & 160 & 59 & 7.8 & 7.7 & 49 & 0.15 & 2.3 & 3.7 & 0.20 & 0.76 & 5.5 \\
\hline 25 & 26.6 & 92 & 110 & 7.1 & 7.5 & 86 & 0.14 & 2.3 & 0.37 & 0.26 & 0.10 & 2.4 \\
\hline 26 & 26.6 & 45 & 48 & 7.2 & 7.5 & 42 & 0.16 & 3.5 & 2.2 & 0.30 & 0.67 & 4.6 \\
\hline 27 & 27.1 & 32 & 47 & 7.3 & 6.9 & 38 & 0.19 & 1.6 & 1.2 & 0.81 & 0.99 & 2.5 \\
\hline 30 & 27.2 & 38 & 3.3 & 7.5 & 7.0 & 5.5 & 0.01 & 0.24 & 0.03 & 0.12 & 0.04 & 1.9 \\
\hline 33 & 26.4 & 96 & 150 & 7.5 & 7.7 & 120 & 0.34 & 0.94 & 0.25 & 0.18 & 0.54 & 3.2 \\
\hline \multicolumn{13}{|c|}{ Nandi-Lower Nyando subcatchment, February 2006} \\
\hline 15 & 16.3 & 110 & 810 & 61 & 7.5 & 380 & 0.49 & 5.8 & 39 & 1.5 & 57 & 23 \\
\hline 16 & 19.5 & 110 & 870 & 59 & 7.6 & 300 & 0.41 & 5.7 & 52 & 1.3 & 67 & 35 \\
\hline 17 & 19.1 & 120 & 880 & 60 & 7.4 & 310 & 0.32 & 5.4 & 56 & 1.4 & 64 & 13 \\
\hline 18 & 20.1 & 100 & 830 & 36 & 7.4 & 260 & 0.15 & 3.2 & 38 & 1.1 & 9.8 & 8.5 \\
\hline 19 & 14.9 & 200 & 380 & 61 & 7.9 & 130 & 0.16 & 5.4 & 14 & 0.80 & 11 & 7.6 \\
\hline 21 & 13.0 & 190 & 180 & 72 & 7.7 & 100 & 0.14 & 0.50 & 0.96 & 1.0 & 0.97 & 0.49 \\
\hline 22 & 15.7 & 250 & 130 & 74 & 7.8 & 61 & 0.17 & 0.92 & 6.3 & 0.3 & 1.9 & 9.9 \\
\hline 23 & 15.4 & 250 & 120 & 60 & 7.9 & 44 & 0.10 & 1.1 & 6.2 & 0.70 & 4.0 & 6.1 \\
\hline 25 & 19.9 & 160 & 120 & 64 & 7.5 & 46 & 0.19 & 2.7 & 0.69 & 0.30 & 24 & 0.22 \\
\hline 26 & 15.6 & 73 & 110 & 65 & 6.9 & 37 & 0.09 & 1.7 & 0.85 & 0.90 & 0.80 & 3.1 \\
\hline 27 & 20.6 & 50 & 86 & 36 & 6.3 & 23 & 0.09 & 1.5 & 1.5 & 0.50 & 0.79 & 3.2 \\
\hline 30 & 16.9 & 42 & 3.2 & 62 & 5.8 & 3.0 & 0.02 & 0.41 & 0.04 & 0.30 & 0.01 & 0.60 \\
\hline 33 & 25.5 & 130 & 280 & 5.3 & 7.1 & 230 & 0.32 & 4.2 & 0.88 & 0.70 & 0.64 & 0.20 \\
\hline
\end{tabular}


Appendix 1: Additional density (ind. $\mathrm{m}^{-2}$ ) and distribution data on benthic macroinvertebrates in the Nyando River catchment in February, May, September and December 2005-2006

\begin{tabular}{|c|c|c|c|c|c|c|c|c|c|c|c|c|c|}
\hline \multirow{2}{*}{ Taxon } & \multicolumn{13}{|c|}{ Site no. } \\
\hline & 1 & 3 & 4 & 5 & 6 & 7 & 8 & 9 & 10 & 11 & 12 & 13 & 14 \\
\hline & \multicolumn{13}{|c|}{ Kericho-Upper Nyando, February 2005} \\
\hline \multicolumn{14}{|l|}{ Turbellaria } \\
\hline \multicolumn{14}{|l|}{ Oligochaeta } \\
\hline Tubificidae & & 3 & 5 & 8 & 3 & & & & & 13 & 2 & & 5 \\
\hline \multicolumn{14}{|l|}{ Hirudinea } \\
\hline Arhynchobdellida & 2 & & & & & & & & & & & & \\
\hline Acariformes & & & & 3 & & & & & & & & & \\
\hline Hydrachnoidea & & & & & 8 & & & 9 & 1 & 8 & 10 & & \\
\hline \multicolumn{14}{|l|}{ Insecta } \\
\hline \multicolumn{14}{|l|}{ Belostomatidae } \\
\hline Sisyridae & & & & & & & & & & & & & \\
\hline Baetidae & 6 & & & 51 & 62 & & & 19 & 17 & 21 & 13 & 33 & 30 \\
\hline Caenidae & 3 & & & 27 & 32 & & & 13 & 10 & 11 & 9 & 23 & 19 \\
\hline Limnephilidae & 5 & & & 9 & 6 & 2 & 3 & 19 & 40 & 32 & 21 & 2 & 56 \\
\hline Perlidae & & & & & 4 & & & & 10 & 14 & 4 & & \\
\hline Zygoptera & 2 & & 4 & & 3 & & & & 4 & 2 & 11 & 2 & 14 \\
\hline Anisoptera & & & & 4 & 6 & & 4 & 6 & 12 & 6 & 13 & & 14 \\
\hline Psephenidae & & & & & 8 & 1 & & & & & 4 & 3 & \\
\hline Elmidae & & & & & 4 & & & & 40 & & 10 & 4 & 17 \\
\hline Culicidae & & & & & 14 & & & & & & 3 & 8 & \\
\hline Athericidae & 7 & & & & & & 4 & 2 & & & 9 & & \\
\hline
\end{tabular}

Mollusca

Corbiculidae

Total

25

5

\begin{tabular}{ccccc}
50 & 3 & 11 & 68 & 134 \\
\hline
\end{tabular}

Turbellaria

Oligochaeta

Tubificidae

Hirudinea

Arhynchobdellida

Acariformes

Hydrachnoidea

Insecta

Belostomatidae

12

12

Sisyridae

Baetidae

Caenidae

Limnephilidae

Perlidae

Zygoptera

Anisoptera

Psephenidae

Elmidae

Culicidae

Athericidae

Mollusca

\begin{tabular}{|c|c|c|c|c|c|c|c|c|c|c|c|c|c|}
\hline Corbiculidae & & 9 & & & 20 & & & & & & 1 & 11 & \\
\hline Total & 41 & 9 & 38 & 26 & 75 & 6 & 16 & 56 & 119 & 117 & 139 & 46 & 65 \\
\hline \multirow{2}{*}{ Taxon } & \multicolumn{13}{|c|}{ Site no. } \\
\hline & 15 & 16 & 17 & 18 & 19 & 21 & 22 & 23 & 25 & 26 & 27 & 30 & 33 \\
\hline & \multicolumn{13}{|c|}{ Nandi-Lower Nyando, May 2005} \\
\hline Turbellaria & & & & & & & & & & 5 & & & \\
\hline \multicolumn{14}{|l|}{ Oligochaeta } \\
\hline Tubificidae & & 2 & & 9 & 25 & & & & 21 & 12 & & & 11 \\
\hline \multicolumn{14}{|l|}{ Hirudinea } \\
\hline \multicolumn{14}{|l|}{ Arhynchobdellida } \\
\hline \multicolumn{14}{|l|}{ Acariformes } \\
\hline Hydrachnoidea & & & & 80 & & & & & & & & & 112 \\
\hline \multicolumn{14}{|l|}{ Insecta } \\
\hline Belostomatidae & 3 & & & & 10 & 30 & 2 & & 37 & 24 & 15 & 5 & 7 \\
\hline \multicolumn{14}{|l|}{ Sisyridae } \\
\hline Baetidae & 15 & & & & 19 & 11 & 32 & 6 & 14 & 7 & 19 & & \\
\hline
\end{tabular}


Appendix 1: (cont.)

\begin{tabular}{|c|c|c|c|c|c|c|c|c|c|c|c|c|c|}
\hline \multirow{2}{*}{ Taxon } & \multicolumn{13}{|c|}{ Site no. } \\
\hline & 15 & 16 & 17 & 18 & 19 & 21 & 22 & 23 & 25 & 26 & 27 & 30 & 33 \\
\hline Caenidae & 10 & & & & 10 & 2 & 25 & 3 & 10 & 4 & 18 & & \\
\hline Limnephilidae & 8 & & & & 11 & 11 & 11 & 9 & 7 & 6 & 6 & & \\
\hline Perlidae & & & & & 5 & 30 & & 18 & 48 & 15 & 38 & 14 & \\
\hline Zygoptera & 4 & & & & 7 & 8 & & 13 & 10 & 3 & 16 & 3 & \\
\hline Anisoptera & & & & & & & & 1 & 1 & & 7 & 2 & \\
\hline Psephenidae & & & & & 2 & 4 & 5 & 1 & 12 & 1 & 18 & 2 & \\
\hline Culicidae & & & & & & 3 & & 8 & & & 15 & & \\
\hline Athericidae & & 1 & & & & & & & & & & & \\
\hline \multicolumn{14}{|l|}{ Mollusca } \\
\hline Corbiculidae & & 1 & & & 17 & & & & 18 & & & & 8 \\
\hline \multirow[t]{2}{*}{ Total } & 40 & 4 & 0 & 89 & 104 & 107 & 87 & 81 & 208 & 82 & 161 & 26 & 148 \\
\hline & \multicolumn{13}{|c|}{ Nandi-Lower Nyando, May 2006} \\
\hline Turbellaria & 3 & & & 2 & & & & 1 & & & & & \\
\hline Tubificidae & 2 & & & & 24 & 3 & 2 & 1 & 7 & 1 & 5 & 3 & 80 \\
\hline \multicolumn{14}{|l|}{ Hirudinea } \\
\hline Arhynchobdellida & & & & 120 & & & & & & & & & 142 \\
\hline \multicolumn{14}{|l|}{ Acariformes } \\
\hline Hydrachnoidea & & & & & 2 & 10 & 14 & 9 & 13 & 8 & 10 & 24 & \\
\hline \multicolumn{14}{|l|}{ Insecta } \\
\hline Belostomatidae & & & & & 10 & 10 & 20 & 15 & 16 & 12 & 26 & 7 & 2 \\
\hline Sisyridae & & & & & & 3 & & & & & & & \\
\hline Baetidae & 17 & & & & 82 & 64 & 30 & 70 & 65 & 23 & 75 & 40 & \\
\hline Caenidae & 14 & & & & 8 & 33 & 23 & 66 & 48 & 20 & 69 & 15 & \\
\hline Limnephilidae & & & & & 2 & 19 & 15 & 13 & 23 & 10 & 12 & 2 & \\
\hline Perlidae & & & & & 3 & 4 & 10 & 33 & 32 & 21 & 7 & 4 & 2 \\
\hline Zygoptera & & & & & 10 & 3 & & 1 & 6 & & 19 & 2 & \\
\hline Anisoptera & & & & & 3 & 3 & & & & & 3 & & \\
\hline Psephenidae & 4 & & & & 1 & & & & 6 & & 10 & & \\
\hline Elmidae & & & & & & 8 & 10 & 3 & 18 & 9 & 9 & & 3 \\
\hline \multicolumn{14}{|l|}{ Mollusca } \\
\hline Corbiculidae & & & & & 8 & & & 3 & 20 & & 8 & & 2 \\
\hline Total & 30 & 0 & & 122 & 104 & 161 & 167 & 218 & 227 & 114 & 245 & 98 & 250 \\
\hline \multirow{2}{*}{ Taxon } & & & & & & & Site $n$ & & & & & & \\
\hline & 1 & 3 & 4 & 5 & 6 & 7 & 8 & 9 & 10 & 11 & 12 & 13 & 14 \\
\hline & & & & & Keric & -Uppe & Jyando & Septen & er 2005 & & & & \\
\hline Turbellaria & 1 & & & & & & & & & & & & \\
\hline Oligochaeta & & & & & & & & & & & & & \\
\hline Tubificidae & 2 & 2 & 11 & 3 & 7 & & & 4 & & & & 4 & \\
\hline $\begin{array}{l}\text { Hirudinea } \\
\text { Arhynchobdellida }\end{array}$ & & & & & & & & & & & & & \\
\hline Acariformes & & & & & & & & & & & & & \\
\hline Hydrachnoidea & 6 & 1 & & 20 & 14 & 10 & 22 & 8 & 10 & 5 & 9 & 1 & 14 \\
\hline Insecta & & & & & & & & & & & & & \\
\hline Belostomatidae & & & & & & 1 & & 1 & & & & & \\
\hline Sisyridae & & & & 10 & & & & & & & & & \\
\hline Baetidae & 140 & 34 & & 11 & 102 & & & 263 & 19 & 26 & 65 & & 94 \\
\hline Caenidae & 107 & 20 & & 9 & 56 & & & 201 & 10 & 4 & 34 & & 34 \\
\hline Limnephilidae & & & & & & & & 1 & & & & & 6 \\
\hline Perlidae & 23 & 4 & & 27 & 9 & 10 & 37 & 5 & 36 & 26 & 16 & & 8 \\
\hline Zygoptera & 3 & 1 & & & 5 & & & & & 2 & & 2 & 4 \\
\hline Anisoptera & 2 & & & 1 & 3 & & & & & 1 & & 1 & 2 \\
\hline Psephenidae & 3 & & & 6 & 2 & & & 5 & 9 & 12 & 2 & & 7 \\
\hline Elmidae & 6 & & & 8 & 10 & & 20 & 4 & 5 & 6 & 5 & 1 & 20 \\
\hline Culicidae & 6 & & & & & & & & & & & & 11 \\
\hline Athericidae & 1 & 4 & & & & & & 7 & & & & & \\
\hline Mollusca & & & & & & & & & & & & & \\
\hline Corbiculidae & 4 & 3 & 2 & 10 & 4 & & & 5 & & 7 & 3 & & \\
\hline Total & 302 & 69 & 13 & 105 & 214 & 21 & 79 & 504 & 89 & 89 & 134 & 9 & 300 \\
\hline
\end{tabular}


Appendix 1: (cont.)

\begin{tabular}{|c|c|c|c|c|c|c|c|c|c|c|c|c|c|}
\hline \multirow{2}{*}{ Taxon } & \multicolumn{13}{|c|}{ Site no. } \\
\hline & 1 & 3 & 4 & 5 & 6 & 7 & 8 & 9 & 10 & 11 & 12 & 13 & 14 \\
\hline & \multicolumn{13}{|c|}{ Kericho-Upper Nyando, September 2006} \\
\hline Turbellaria & & & & 4 & & & & & 2 & 3 & 1 & 2 & \\
\hline \multicolumn{14}{|l|}{ Oligochaeta } \\
\hline Tubificidae & & 10 & 39 & 19 & 7 & 17 & 6 & 2 & 1 & 6 & 8 & & 12 \\
\hline \multicolumn{14}{|l|}{ Hirudinea } \\
\hline Arhynchobdellida & & & 7 & & & & & & & & & & \\
\hline \multicolumn{14}{|l|}{ Acariformes } \\
\hline Hydrachnoidea & 4 & 2 & & 11 & 19 & 4 & 18 & 11 & 13 & 9 & 11 & & 11 \\
\hline \multicolumn{14}{|l|}{ Insecta } \\
\hline Belostomatidae & 99 & 14 & 15 & 13 & 8 & 13 & 11 & 19 & 16 & 9 & 9 & 11 & 13 \\
\hline Sisyridae & 8 & & & 4 & & & & & & & & & \\
\hline Baetidae & 84 & 80 & & 12 & 11 & & 12 & 10 & 95 & 6 & 12 & & 104 \\
\hline Caenidae & 71 & 56 & & 14 & 9 & & 4 & 71 & 11 & 4 & 12 & & 61 \\
\hline Limnephilidae & 98 & 3 & 30 & 16 & 9 & 11 & 21 & 2 & 16 & 19 & 21 & & 12 \\
\hline Perlidae & 6 & & & 9 & 83 & 8 & 9 & 7 & 2 & 18 & 1 & 1 & \\
\hline Zygoptera & & & & & 2 & & & & & 1 & 8 & & 4 \\
\hline Anisoptera & & & & 8 & 7 & & & & & 1 & 2 & & 7 \\
\hline Psephenidae & & & & 9 & 7 & & & & 2 & & 3 & 1 & 4 \\
\hline Elmidae & & & & 9 & 3 & 4 & 4 & 2 & 14 & & 1 & & 2 \\
\hline Culicidae & & & & & & & & & & & 2 & & \\
\hline Athericidae & & & & & & & & 1 & & & & & \\
\hline
\end{tabular}

Mollusca

Corbiculidae

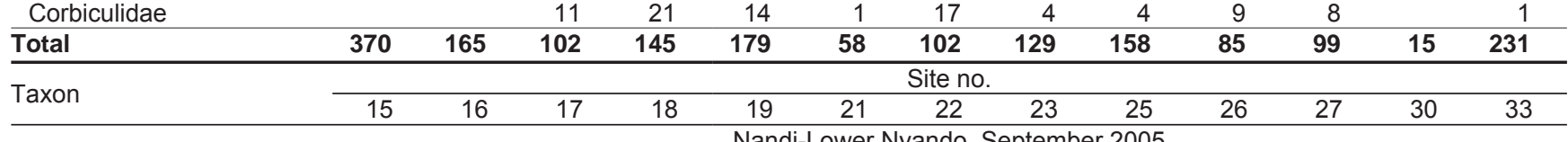

Turbellaria

Oligochaeta

Tubificidae

Hirudinea

Arhynchobdellida

Acariformes

Hydrachnoidea

Insecta

Belostomatida

Sisyridae

Baetidae

Caenidae

Limnephilidae

Perlidae

Zygoptera

Anisoptera

Psephenidae

Elmidae

Culicidae

Athericidae

Mollusca

Corbiculidae

Nandi-Lower Nyando, September 2005

Total

42

Turbellaria

\begin{tabular}{|c|c|c|c|}
\hline 5 & 0 & 19 & 83 \\
\hline
\end{tabular}

Oligochaeta

Tubificidae

Hirudinea

Arhynchobdellida

10

5

Acariformes

Hydrachnoidea

Insecta

Belostomatidae

Sisyridae

Baetidae

3

15

6

Nandi-Lower Nyando, September 2006

$7 \quad 9$

210

108

$\begin{array}{rrrrrrrrr}2 & 10 & 2 & & 19 & 22 & 85 & 2 & 2 \\ 19 & 2 & 19 & 2 & 4 & 8 & 9 & & \\ 10 & 1 & 11 & & 2 & 4 & 14 & & \\ & & 11 & & 3 & & & & \\ 2 & 11 & & 10 & 21 & 14 & 11 & 6 & \\ 3 & 6 & & 4 & 8 & 2 & 9 & 4 & \\ & & & 1 & 1 & & 7 & 2 & \\ 6 & 1 & 7 & 3 & 1 & 1 & 6 & 2 & \\ 7 & 9 & 8 & 11 & 13 & 8 & 4 & & 6\end{array}$

6

11

$\begin{array}{ll}9 & 14\end{array}$

14 


\begin{tabular}{|c|c|c|c|c|c|c|c|c|c|c|c|c|c|}
\hline \multirow{2}{*}{ Taxon } & \multicolumn{13}{|c|}{ Site no. } \\
\hline & 15 & 16 & 17 & 18 & 19 & 21 & 22 & 23 & 25 & 26 & 27 & 30 & 33 \\
\hline Caenidae & 2 & & & & 6 & 9 & 10 & 40 & 3 & & 8 & 2 & \\
\hline Limnephilidae & 3 & & & & 2 & 9 & 14 & 6 & 9 & 2 & 12 & 11 & \\
\hline Perlidae & 1 & & & & & 5 & 7 & 2 & 8 & 6 & 6 & 5 & 3 \\
\hline Zygoptera & & & & & & 3 & 2 & & & & 3 & 6 & \\
\hline Anisoptera & 2 & & & & & 6 & 4 & 3 & 7 & & 12 & 1 & \\
\hline Psephenidae & & & & & & & & & 2 & & 13 & & \\
\hline Culicidae & & & & & 2 & 2 & & & & & & 2 & 10 \\
\hline Athericidae & 3 & & & & & & & 2 & & & 9 & & \\
\hline
\end{tabular}

Corbiculidae

\begin{tabular}{|c|c|c|c|c|c|c|c|c|c|c|c|c|c|}
\hline Corbiculidae & 3 & & & & 2 & & & & 8 & & & & 4 \\
\hline Total & 24 & 0 & 0 & 110 & 67 & 71 & 86 & 140 & 67 & 31 & 109 & 72 & 178 \\
\hline \multirow{2}{*}{ Taxon } & \multicolumn{13}{|c|}{ Site no. } \\
\hline & 1 & 3 & 4 & 5 & 6 & 7 & 8 & 9 & 10 & 11 & 12 & 13 & 14 \\
\hline
\end{tabular}

Turbellaria

Oligochaeta

Tubificidae

12

Hirudinea

Arhynchobdellida

Acariformes

\begin{tabular}{|c|c|c|c|c|c|c|c|c|c|c|c|c|c|}
\hline Hydrachnoidea & 20 & 2 & 10 & 13 & 12 & 4 & 12 & 11 & 12 & 13 & 6 & & 12 \\
\hline \multicolumn{14}{|l|}{ Insecta } \\
\hline Belostomatidae & 18 & 1 & 11 & 9 & 11 & 1 & 15 & 5 & 9 & 10 & 7 & 2 & 15 \\
\hline Sisyridae & & & & 7 & & & & & & & & & \\
\hline Baetidae & 108 & 3 & & 100 & 99 & 3 & 20 & 65 & 104 & 92 & 94 & & 112 \\
\hline Caenidae & 31 & 11 & & 34 & 72 & & 4 & 24 & 38 & 31 & 10 & & 38 \\
\hline Limnephilidae & 6 & 9 & 2 & 17 & 10 & 3 & 16 & 5 & 7 & 41 & 41 & 1 & 18 \\
\hline Perlidae & 13 & 8 & & 18 & 11 & 2 & 8 & 12 & 21 & 20 & 11 & 1 & 17 \\
\hline Zygoptera & 21 & & & & 7 & & & & 1 & 2 & & 2 & \\
\hline Anisoptera & 9 & & & 7 & 6 & & & & & & & 2 & 1 \\
\hline Psephenidae & 8 & 1 & 4 & & 3 & & & & & & & & 2 \\
\hline Elmidae & 10 & 3 & 2 & 4 & 4 & 1 & 5 & 11 & 6 & 1 & 1 & 4 & 11 \\
\hline Culicidae & 5 & & & & & & & & & & & & 6 \\
\hline Athericidae & & 4 & & & & & & 12 & & & & & \\
\hline
\end{tabular}

Athericidae

Mollusca

\begin{tabular}{|c|c|c|c|c|c|c|c|c|c|c|c|c|c|}
\hline Corbiculidae & 2 & 1 & 2 & 3 & 1 & & & 1 & & 2 & 2 & 2 & 7 \\
\hline Total & 265 & 62 & 46 & 234 & 240 & 14 & 89 & 147 & 202 & 213 & 181 & 15 & 256 \\
\hline & \multicolumn{13}{|c|}{ Kericho-Upper Nyando, December 2006} \\
\hline Turbellaria & 3 & & & & & & & & & & & & \\
\hline \multicolumn{14}{|l|}{ Oligochaeta } \\
\hline Tubificidae & 17 & & 21 & 2 & 1 & 1 & 5 & & & 4 & 9 & & 20 \\
\hline \multicolumn{14}{|l|}{$\begin{array}{l}\text { Hirudinea } \\
\text { Arhynchobdellida }\end{array}$} \\
\hline \multicolumn{14}{|l|}{ Acariformes } \\
\hline Hydrachnoidea & 19 & 31 & 12 & 29 & 32 & 2 & 20 & 26 & 4 & 12 & 9 & 2 & 17 \\
\hline \multicolumn{14}{|l|}{ Insecta } \\
\hline Belostomatidae & 20 & 2 & 10 & 24 & 6 & 1 & 2 & 7 & 4 & 13 & 12 & 4 & 2 \\
\hline Sisyridae & & & & 2 & & & & & & & & & \\
\hline Baetidae & 105 & 86 & & 101 & 110 & & 21 & 3 & 107 & 61 & 54 & & 123 \\
\hline Caenidae & 21 & 72 & & 86 & 96 & & 17 & 61 & 84 & 54 & 41 & & 98 \\
\hline Limnephilidae & & & & & & & & & 1 & & 2 & & 6 \\
\hline Zygoptera & 10 & 7 & & 55 & 25 & 12 & 12 & 18 & 9 & 17 & 69 & 9 & 15 \\
\hline Anisoptera & 15 & 2 & & 6 & 42 & 9 & 8 & 27 & 12 & 9 & 11 & 5 & 10 \\
\hline Psephenidae & 3 & & 2 & & 5 & & & & & & 2 & 1 & \\
\hline Elmidae & & & & 36 & 8 & & & & & & 1 & 2 & \\
\hline Culicidae & 1 & 9 & 13 & & 1 & 17 & & & & & 2 & 1 & \\
\hline Athericidae & 11 & 4 & 2 & 7 & 9 & 1 & 1 & 8 & 6 & 7 & 2 & 3 & 10 \\
\hline Mollusca & & & & & & & & & & & & & 1 \\
\hline Corbiculidae & 1 & 6 & & & & & & 6 & & & & & \\
\hline Total & 227 & 219 & 60 & 348 & 335 & 43 & 86 & 156 & 227 & 164 & 214 & 27 & 302 \\
\hline
\end{tabular}


Appendix 1: (cont.)

\begin{tabular}{|c|c|c|c|c|c|c|c|c|c|c|c|c|c|}
\hline \multirow{2}{*}{ Taxon } & \multicolumn{13}{|c|}{ Site no. } \\
\hline & 15 & 16 & 17 & 18 & 19 & 21 & 22 & 23 & 25 & 26 & 27 & 30 & 33 \\
\hline & \multicolumn{13}{|c|}{ Nandi-Lower Nyando, December 2005} \\
\hline Turbellaria & & & & & & & & & & 2 & & & \\
\hline \multicolumn{14}{|l|}{ Oligochaeta } \\
\hline Tubificidae & & 1 & & 9 & 16 & & & & 10 & 9 & & & 7 \\
\hline \multicolumn{14}{|l|}{ Hirudinea } \\
\hline \multicolumn{14}{|l|}{ Arhynchobdellida } \\
\hline \multicolumn{14}{|l|}{ Acariformes } \\
\hline Hydrachnoidea & & & & 7 & & & & & & & & & 98 \\
\hline \multicolumn{14}{|l|}{ Insecta } \\
\hline Belostomatidae & 1 & & & & 9 & 17 & 2 & & 19 & 9 & 9 & 2 & 5 \\
\hline \multicolumn{14}{|l|}{ Sisyridae } \\
\hline Baetidae & 9 & & & & 9 & 9 & 11 & 7 & 9 & 3 & 11 & & \\
\hline Caenidae & 7 & & & & 7 & & 13 & 1 & 10 & 2 & 7 & & \\
\hline Limnephilidae & 5 & & & & 10 & 4 & 9 & 4 & 9 & 3 & 4 & & \\
\hline Perlidae & & & & & 8 & & & 11 & 12 & 11 & 2 & 9 & \\
\hline Zygoptera & 3 & & & & 3 & 6 & & 11 & 13 & 1 & 9 & 2 & \\
\hline Anisoptera & & & & & & & & & 11 & & 10 & 1 & \\
\hline Psephenidae & & & & & 6 & 2 & 3 & & 12 & & 12 & & \\
\hline Elmidae & & & & & 14 & 9 & 7 & 19 & 12 & 13 & 6 & & 6 \\
\hline Culicidae & & & & & & 2 & & 5 & & & 4 & & \\
\hline
\end{tabular}

Mollusca

\begin{tabular}{|c|c|c|c|c|c|c|c|c|c|c|c|c|c|}
\hline \multirow{2}{*}{$\begin{array}{l}\text { Corbiculidae } \\
\text { Total }\end{array}$} & \multicolumn{3}{|c|}{1} & \multicolumn{3}{|c|}{11} & \multicolumn{5}{|c|}{11} & \multicolumn{2}{|r|}{3} \\
\hline & 25 & 3 & 0 & 16 & 93 & 49 & 45 & 58 & 128 & 53 & 74 & 14 & 119 \\
\hline & \multicolumn{13}{|c|}{ Nandi-Lower Nyando, December 2006} \\
\hline Turbellaria & 1 & & & 3 & & & & 2 & & & & & \\
\hline \multicolumn{14}{|l|}{ Oligochaeta } \\
\hline Tubificidae & 1 & & & & 19 & 1 & & 1 & 4 & & 7 & 1 & 74 \\
\hline \multicolumn{14}{|l|}{ Hirudinea } \\
\hline Arhynchobdellida & & & & 109 & & & & & & & & & 139 \\
\hline \multicolumn{14}{|l|}{ Acariformes } \\
\hline Hydrachnoidea & & & & & 1 & 8 & 11 & 7 & 9 & 2 & 8 & 15 & \\
\hline \multicolumn{14}{|l|}{ Insecta } \\
\hline Belostomatidae & & & & & 9 & 11 & 12 & 9 & 9 & 3 & 12 & 5 & 1 \\
\hline Sisyridae & & & & & & 4 & & & & & & & \\
\hline Baetidae & 10 & & & & 67 & 59 & 11 & 65 & 52 & 7 & 69 & 31 & \\
\hline Caenidae & 9 & & & & 9 & 21 & 17 & 59 & 41 & 3 & 54 & 9 & \\
\hline Limnephilidae & & & & & 1 & 13 & 13 & 9 & 17 & 5 & 10 & 1 & \\
\hline Perlidae & & & & & 1 & 1 & 9 & 21 & 19 & 9 & 5 & 1 & 1 \\
\hline Zygoptera & & & & & 18 & 1 & & 2 & 4 & & 12 & 1 & \\
\hline Anisoptera & & & & & 2 & 2 & & & & & 1 & & \\
\hline Psephenidae & 3 & & & & & & & & 2 & & 7 & & \\
\hline Elmidae & & & & & & 5 & 7 & 1 & 11 & 7 & 7 & & 1 \\
\hline Culicidae & & & & & & & 1 & 3 & 1 & & 1 & & 11 \\
\hline Athericidae & & & & & & & & 2 & & & 4 & & \\
\hline \multicolumn{14}{|l|}{ Mollusca } \\
\hline Corbiculidae & & & & & 5 & & & 1 & 9 & & 3 & & 1 \\
\hline Total & 24 & 0 & 0 & 112 & 132 & 126 & 81 & 182 & 178 & 36 & 200 & 64 & 228 \\
\hline
\end{tabular}


Appendix 2: Additional physical and chemical parameter values at sampling sites in the Nyando River catchment in February, May, September and December 2005-2006

\begin{tabular}{|c|c|c|c|c|c|c|c|c|c|c|c|c|}
\hline $\begin{array}{l}\text { Site } \\
\text { no. }\end{array}$ & $\begin{array}{c}\text { Temp. } \\
\left({ }^{\circ} \mathrm{C}\right)\end{array}$ & $\begin{array}{l}\text { Conductivity } \\
\left(\mu S \mathrm{~cm}^{-1}\right)\end{array}$ & $\begin{array}{c}\text { TSS } \\
\left(\mathrm{mg} \mathrm{l}^{-1}\right)\end{array}$ & $\begin{array}{c}\mathrm{DO} \\
\left(\mathrm{mg} \mathrm{l}^{-1}\right)\end{array}$ & $\mathrm{pH}$ & $\begin{array}{c}\text { Turbidity } \\
\text { (NTU) }\end{array}$ & $\begin{array}{c}\text { TP } \\
\left(\mathrm{mg} \mathrm{l}^{-1}\right)\end{array}$ & $\begin{array}{c}\text { TN } \\
\left(\mathrm{mg} \mathrm{l}^{-1}\right)\end{array}$ & $\begin{array}{c}\text { Area } \\
\left(\mathrm{m}^{2}\right)\end{array}$ & $\begin{array}{c}\text { Mean } \\
\text { velocity } \\
\left(\mathrm{m} \mathrm{s}^{-1}\right)\end{array}$ & $\begin{array}{c}\text { Discharge } \\
\left(\mathrm{m}^{3} \mathrm{~s}^{-1}\right)\end{array}$ & $\begin{array}{c}\text { River } \\
\text { width } \\
(\mathrm{m})\end{array}$ \\
\hline \multicolumn{13}{|c|}{ Kericho-Upper Nyando, February 2005} \\
\hline 1 & 27.1 & 120 & 76 & 7.7 & 7.8 & 126 & 0.21 & 3.65 & 0.44 & 0.64 & 0.28 & 3.7 \\
\hline 3 & 28.1 & 78 & 32 & 7.0 & 7.9 & 62 & 0.08 & 3.44 & 0.34 & 0.38 & 0.13 & 2.6 \\
\hline 4 & 28.1 & 96 & 77 & 7.2 & 8.1 & 62 & 0.11 & 2.71 & 1.75 & 0.46 & 0.81 & 7.0 \\
\hline 5 & 27.7 & 111 & 63 & 8.2 & 8.0 & 80 & 0.16 & 3.81 & 4.87 & 0.43 & 2.09 & 6.2 \\
\hline 6 & 28.1 & 103 & 62 & 7.4 & 8.0 & 103 & 0.13 & 2.92 & 5.41 & 0.39 & 2.15 & 7.3 \\
\hline 7 & 27.7 & 76 & 126 & 7.2 & 7.9 & 133 & 0.15 & 2.15 & 0.88 & 0.53 & 0.45 & 2.0 \\
\hline 8 & 27.3 & 94 & 193 & 7.6 & 7.9 & 149 & 0.18 & 3.12 & 6.76 & 0.60 & 0.62 & 9.5 \\
\hline 9 & 27.3 & 81 & 167 & 7.2 & 9.8 & 133 & 0.23 & 2.71 & 1.17 & 0.56 & 0.64 & 4.5 \\
\hline 10 & 27.0 & 167 & 217 & 8.3 & 7.7 & 142 & 0.17 & 2.57 & 2.32 & 0.39 & 0.91 & 6.7 \\
\hline 11 & 27.3 & 170 & 194 & 7.5 & 8.3 & 148 & 0.22 & 1.21 & 0.42 & 0.61 & 0.26 & 2.3 \\
\hline 12 & 27.2 & 163 & 149 & 8.0 & 8.2 & 141 & 0.18 & 2.49 & 1.80 & 0.56 & 1.04 & 6.6 \\
\hline 13 & 27.2 & 169 & 65 & 8.4 & 7.9 & 56 & 0.30 & 1.89 & 2.06 & 0.34 & 0.71 & 7.5 \\
\hline 14 & 27.7 & 125 & 240 & 7.1 & 8.2 & 160 & 0.21 & 2.61 & 33.30 & 0.38 & 12.91 & 27.0 \\
\hline \multicolumn{13}{|c|}{ Kericho-Upper Nyando, February 2006} \\
\hline 1 & 15.4 & 124 & 67 & 5.6 & 7.3 & 73 & 0.15 & 1.41 & 0.57 & 2.40 & 3.80 & 1.49 \\
\hline 3 & 18.4 & 65 & 22 & 6.4 & 6.9 & 76 & 0.08 & 2.18 & 0.9 & 0.50 & 2.70 & 0.46 \\
\hline 4 & 18.4 & 80 & 53 & 6.4 & 7.1 & 89 & 0.08 & 2.30 & 1.19 & 0.63 & 6.0 & 0.76 \\
\hline 5 & 17.5 & 119 & 58 & 7.4 & 7.5 & 93 & 0.07 & 1.60 & 2.00 & 0.60 & 4.50 & 1.20 \\
\hline 6 & 12.1 & 115 & 53 & 4.8 & 7.5 & 84 & 0.11 & 1.72 & 4.4 & 0.30 & 7.40 & 1.20 \\
\hline 7 & 15.4 & 68 & 118 & 4.5 & 7.8 & 30 & 0.21 & 1.39 & 0.22 & 0.20 & 1.70 & 0.10 \\
\hline 8 & 15.9 & 84 & 182 & 7.4 & 7.4 & 81 & 0.14 & 1.58 & 3.97 & 0.30 & 8.1 & 1.00 \\
\hline 9 & 19.8 & 79 & 141 & 4.5 & 7.5 & 35 & 0.18 & 1.55 & 0.73 & 0.20 & 3.50 & 0.10 \\
\hline 10 & 25.8 & 159 & 89 & 5.7 & 8.1 & 37 & 0.21 & 1.16 & 2.60 & 0.60 & 8.00 & 1.56 \\
\hline 11 & 25.6 & 148 & 38 & 5.2 & 7.1 & 27 & 0.23 & 1.44 & 0.85 & 0.30 & 2.70 & 0.23 \\
\hline 12 & 25.7 & 158 & 64 & 5.9 & 8.2 & 32 & 0.22 & 1.38 & 4.61 & 0.33 & 11.30 & 1.54 \\
\hline 13 & 25.4 & 158 & 97 & 5.2 & 8.0 & 39 & 0.21 & 0.43 & 2.67 & 0.27 & 8.40 & 0.73 \\
\hline 14 & 25.8 & 118 & 215 & 5.4 & 7.8 & 94 & 0.18 & 1.29 & 11.08 & 0.80 & 24.80 & 0.94 \\
\hline \multicolumn{13}{|c|}{ Nandi-Lower Nyando, May 2005} \\
\hline 15 & 27.0 & 130 & 206 & 7.0 & 7.9 & 156 & 0.48 & 5.03 & 34.50 & 0.40 & 28.00 & 29.0 \\
\hline 16 & 27.4 & 126 & 331 & 7.4 & 7.6 & 263 & 0.49 & 5.00 & 27.52 & 1.02 & 27.96 & 28.6 \\
\hline 17 & 27.2 & 127 & 334 & 7.2 & 7.5 & 268. & 0.50 & 4.97 & 28.40 & 1.34 & 28.40 & 29.0 \\
\hline 18 & 26.1 & 47 & 137 & 7.7 & 7.4 & 122 & 0.23 & 5.00 & 2.85 & 0.54 & 1.65 & 6.2 \\
\hline 19 & 26.8 & 110 & 43 & 6.8 & 7.3 & 189 & 0.29 & 3.09 & 7.32 & 0.56 & 4.09 & 7.0 \\
\hline 21 & 26.8 & 108 & 214 & 6.2 & 7.4 & 188 & 0.33 & 1.38 & 2.73 & 0.64 & 1.75 & 5.0 \\
\hline 22 & 27.3 & 157 & 70 & 7.9 & 7.7 & 77 & 0.20 & 1.92 & 5.13 & 0.65 & 3.34 & 9.3 \\
\hline 23 & 27.1 & 160 & 59 & 7.8 & 7.7 & 49 & 0.15 & 2.34 & 3.67 & 0.20 & 0.76 & 5.5 \\
\hline 25 & 26.6 & 92 & 109 & 7.1 & 7.4 & 87 & 0.14 & 2.31 & 0.37 & 0.26 & 0.10 & 2.4 \\
\hline 26 & 26.6 & 45 & 48 & 7.3 & 7.5 & 42 & 0.16 & 3.48 & 2.23 & 0.30 & 0.67 & 4.6 \\
\hline 27 & 27.1 & 32 & 47 & 7.3 & 6.9 & 38 & 0.19 & 1.59 & 1.21 & 0.81 & 0.99 & 2.5 \\
\hline 30 & 27.2 & 37 & 3.33 & 7.5 & 7.0 & 5.5 & 0.01 & 0.24 & 0.03 & 0.12 & 0.04 & 1.9 \\
\hline 33 & 26.4 & 96 & 146 & 7.5 & 7.7 & 124 & 0.34 & 0.94 & 0.25 & 0.18 & 0.54 & 3.2 \\
\hline \multicolumn{13}{|c|}{ Nandi-Lower Nyando, May 2006} \\
\hline 15 & 27.0 & 130 & 207 & 7.0 & 7.9 & 156 & 0.48 & 5.03 & 10.50 & 0.45 & 11.00 & 16.00 \\
\hline 16 & 27.5 & 126 & 331 & 7.4 & 7.6 & 263 & 0.23 & 4.04 & 24.50 & 0.46 & 12.50 & 32.00 \\
\hline 17 & 27.1 & 128 & 337 & 7.4 & 7.8 & 98 & 0.21 & 4.29 & 1.01 & 0.36 & 1.10 & 3.94 \\
\hline 18 & 26.1 & 47 & 26 & 7.7 & 7.4 & 122 & 0.29 & 3.12 & 2.15 & 0.76 & 1.65 & 5.80 \\
\hline 19 & 25.0 & 107 & 217 & 7.9 & 7.5 & 138 & 0.23 & 1.9 & 1.34 & 0.38 & 1.98 & 4.15 \\
\hline 21 & 26.9 & 108 & 214 & 6.2 & 7.4 & 188 & 0.33 & 1.38 & 1.98 & 0.31 & 0.61 & 4.40 \\
\hline 22 & 27.3 & 157 & 70 & 7.9 & 7.7 & 77 & 0.20 & 1.92 & 3.39 & 0.33 & 1.14 & 8.10 \\
\hline 23 & 27.1 & 160 & 59 & 7.8 & 7.7 & 49 & 0.15 & 2.34 & 0.78 & 0.62 & 0.48 & 4.60 \\
\hline 25 & 26.6 & 92 & 109 & 7.1 & 7.4 & 87 & 0.14 & 2.31 & 0.32 & 0.27 & 0.09 & 0.32 \\
\hline 26 & 26.7 & 45 & 48 & 7.3 & 7.5 & 42 & 0.16 & 3.48 & 0.73 & 0.60 & 0.04 & 2.70 \\
\hline 27 & 26.0 & 32. & 47 & 7.4 & 6.9 & 38 & 0.18 & 1.59 & 0.54 & 0.26 & 0.23 & 2.60 \\
\hline 30 & 27.2 & 37 & 0.09 & 7.5 & 7.0 & 5.5 & 0.01 & 0.07 & 0.04 & 0.25 & 0.10 & 0.40 \\
\hline 33 & 26.4 & 96. & 146. & 7.1 & 7.7 & 124 & 0.37 & 3.97 & 0.5 & 0.86 & 0.04 & 1.80 \\
\hline
\end{tabular}




\begin{tabular}{|c|c|c|c|c|c|c|c|c|c|c|c|c|}
\hline $\begin{array}{l}\text { Site } \\
\text { no. }\end{array}$ & $\begin{array}{l}\text { Temp. } \\
\left({ }^{\circ} \mathrm{C}\right)\end{array}$ & $\begin{array}{l}\text { Conductivity } \\
\left(\mu \mathrm{S} \mathrm{cm}^{-1}\right)\end{array}$ & $\begin{array}{c}\text { TSS } \\
\left(\mathrm{mg} \mathrm{l}^{-1}\right)\end{array}$ & $\begin{array}{c}\mathrm{DO} \\
\left(\mathrm{mg} \mathrm{l}^{-1}\right)\end{array}$ & $\mathrm{pH}$ & $\begin{array}{l}\text { Turbidity } \\
\text { (NTU) }\end{array}$ & $\begin{array}{c}\text { TP } \\
\left(\mathrm{mg} \mathrm{l}^{-1}\right)\end{array}$ & $\begin{array}{c}\text { TN } \\
\left(\mathrm{mg} \mathrm{l}^{-1}\right)\end{array}$ & $\begin{array}{l}\text { Area } \\
\left(\mathrm{m}^{2}\right)\end{array}$ & $\begin{array}{c}\text { Mean } \\
\text { velocity } \\
\left(\mathrm{m} \mathrm{s}^{-1}\right)\end{array}$ & $\begin{array}{c}\text { Discharge } \\
\left(\mathrm{m}^{3} \mathrm{~s}^{-1}\right)\end{array}$ & $\begin{array}{c}\text { River } \\
\text { width } \\
(\mathrm{m})\end{array}$ \\
\hline \multicolumn{13}{|c|}{ Kericho-Upper Nyando, September 2005} \\
\hline 1 & 26.3 & 60 & 500 & 9.0 & 7.0 & 370 & 0.25 & 4.2 & 1.9 & 1.1 & 2.1 & 3.7 \\
\hline 3 & 25.9 & 66 & 270 & 7.5 & 6.8 & 150 & 0.19 & 4.8 & 0.47 & 0.34 & 0.16 & 2.2 \\
\hline 4 & 22.9 & 58 & 130 & 8.2 & 6.8 & 190 & 0.29 & 3.8 & 4.6 & 0.77 & 3.6 & 2.6 \\
\hline 5 & 26.4 & 58 & 410 & 7.7 & 7.1 & 340 & 0.34 & 3.3 & 8.5 & 0.92 & 7.9 & 6.1 \\
\hline 7 & 26.2 & 200 & 12 & 8.4 & 7.9 & 33 & 0.17 & 3.3 & 0.26 & 0.23 & 0.06 & 1.6 \\
\hline 8 & 26.1 & 68 & 420 & 8.4 & 7.1 & 280 & 0.37 & 3.5 & 0.38 & 0.17 & 0.06 & 2.0 \\
\hline 9 & 26.5 & 90 & 46 & 7.9 & 7.6 & 84 & 0.22 & 3.3 & 0.61 & 0.23 & 0.14 & 3.5 \\
\hline 10 & 26.0 & 100 & 200 & 8.6 & 7.5 & 150 & 0.28 & 3.4 & 3.8 & 0.69 & 2.6 & 9.6 \\
\hline 11 & 25.1 & 370 & 34 & 5.6 & 8.1 & 39 & 1.7 & 4.3 & 0.56 & 0.39 & 0.22 & 1.8 \\
\hline 12 & 27.2 & 200 & 130 & 7.5 & 8.2 & 29 & 0.25 & 2.9 & 0.88 & 0.84 & 0.74 & 3.0 \\
\hline 13 & 26.9 & 120 & 130 & 7.6 & 7.8 & 28 & 0.41 & 3.2 & 0.81 & 0.22 & 0.18 & 7.6 \\
\hline \multicolumn{13}{|c|}{ Kericho-Upper Nyando, September 2006} \\
\hline 1 & 26.3 & 60 & 500 & 8.0 & 7.1 & 370 & 0.25 & 4.2 & 3.7 & 0.19 & 0.72 & 8.2 \\
\hline 3 & 26.5 & 66 & 270 & 7.5 & 6.7 & 150 & 0.19 & 4.8 & 0.47 & 0.34 & 0.16 & 2.2 \\
\hline 4 & 26.2 & 58 & 140 & 8.2 & 6.8 & 190 & 0.29 & 3.8 & 2.5 & 0.51 & 1.3 & 6.8 \\
\hline 5 & 26.4 & 58 & 400 & 7.6 & 7.1 & 340 & 0.34 & 3.3 & 3.5 & 0.45 & 1.5 & 5.7 \\
\hline 6 & 26.8 & 67 & 430 & 6.6 & 7.1 & 270 & 0.32 & 3.5 & 5.2 & 0.42 & 2.2 & 7.7 \\
\hline 7 & 26.2 & 200 & 27 & 8.4 & 7.9 & 33 & 0.17 & 3.3 & 0.26 & 0.23 & 0.06 & 1.6 \\
\hline 8 & 26.1 & 68 & 430 & 8.3 & 7.1 & 280 & 0.37 & 3.5 & 5.0 & 0.41 & 2.1 & 9.3 \\
\hline 9 & 26.5 & 90 & 47 & 7.9 & 7.6 & 84 & 0.22 & 3.3 & 0.61 & 0.23 & 0.14 & 3.5 \\
\hline 10 & 26.0 & 100 & 200 & 7.9 & 7.6 & 87 & 0.28 & 3.4 & 3.8 & 0.69 & 2.6 & 9.6 \\
\hline 11 & 25.1 & 370 & 34 & 5.6 & 8.1 & 39 & 1.72 & 4.3 & 0.56 & 0.39 & 0.22 & 1.8 \\
\hline 12 & 27.4 & 200 & 130 & 7.5 & 8.2 & 29 & 0.25 & 2.9 & 5.6 & 0.64 & 3.4 & 14.0 \\
\hline 13 & 25.9 & 60 & 130 & 8.3 & 7.1 & 370 & 0.41 & 3.2 & 0.81 & 0.22 & 0.18 & 7.6 \\
\hline 14 & 26.7 & 120 & 190 & 7.6 & 7.5 & 90 & 0.27 & 2.6 & 10 & 0.33 & 3.4 & 24.0 \\
\hline \multicolumn{13}{|c|}{ Nandi-Lower Nyando, September 2005} \\
\hline 15 & 26.5 & 120 & 230 & 7.8 & 7.4 & 90 & 0.34 & 4.0 & 40.0 & 0.52 & 20.0 & 33.0 \\
\hline 18 & 26.2 & 48 & 100 & 8.4 & 7.0 & 92 & 0.27 & 2.6 & 3.7 & 0.19 & 0.72 & 8.2 \\
\hline 19 & 27.3 & 120 & 240 & 7.7 & 7.7 & 100 & 0.46 & 3.2 & 3.5 & 0.57 & 2.0 & 11.0 \\
\hline 21 & 26.2 & 180 & 78 & 7.1 & 7.9 & 67 & 0.13 & 2.2 & 8.5 & 0.92 & 7.8 & 7.1 \\
\hline 22 & 25.7 & 120 & 290 & 7.2 & 8.0 & 100 & 0.19 & 3.6 & 1.9 & 0.25 & 0.49 & 4.3 \\
\hline 23 & 25.4 & 250 & 44 & 8.6 & 8.1 & 33 & 0.15 & 2.4 & 2.1 & 0.49 & 0.49 & 4.8 \\
\hline 25 & 25.0 & 200 & 92 & 25.0 & 7.8 & 60 & 0.19 & 3.4 & 0.43 & 0.37 & 0.16 & 2.4 \\
\hline 26 & 26.0 & 71 & 52 & 7.7 & 7.49 & 38 & 0.07 & 3.6 & 0.60 & 0.46 & 0.27 & 1.7 \\
\hline 27 & 24.5 & 68 & 34 & 6.0 & 7.19 & 27 & 0.06 & 2.0 & 0.95 & 0.30 & 0.29 & 2.6 \\
\hline 30 & 25.5 & 68 & 36.0 & 6.0 & 7.19 & 27 & 0.01 & 0.02 & 1.5 & 0.51 & 0.77 & 2.6 \\
\hline 33 & 25.3 & 130 & 8.00 & 7.2 & 6.21 & 6.5 & 0.96 & 2.9 & 0.99 & 0.10 & 0.12 & 0.4 \\
\hline \multicolumn{13}{|c|}{ Nandi-Lower Nyando, September 2006} \\
\hline 15 & 26.5 & 120 & 230 & 7.8 & 7.4 & 90 & 0.34 & 4.0 & 40.0 & 0.52 & 20.0 & 33.0 \\
\hline 16 & 27.3 & 100 & 340 & 6.5 & 7.2 & 160 & 0.46 & 3.8 & 35.0 & 0.53 & 18.0 & 49.0 \\
\hline 17 & 26.7 & 130 & 340 & 7.8 & 7.5 & 190 & 0.49 & 3.3 & 20.0 & 0.93 & 18.0 & 17.0 \\
\hline 18 & 26.2 & 48 & 100 & 8.4 & 7.0 & 92 & 0.27 & 2.6 & 3.7 & 0.19 & 0.72 & 8.2 \\
\hline 19 & 27.3 & 120 & 240 & 7.7 & 7.8 & 100 & 0.46 & 3.2 & 3.5 & 0.57 & 2.0 & 11.0 \\
\hline 21 & 26.2 & 180 & 78 & 7.1 & 7.9 & 67 & 0.13 & 2.2 & 8.5 & 0.92 & 7.8 & 7.1 \\
\hline 22 & 25.7 & 120 & 290 & 7.2 & 8.0 & 100 & 0.19 & 3.6 & 1.9 & 0.25 & 0.49 & 4.3 \\
\hline 23 & 25.4 & 250 & 44 & 8.6 & 8.1 & 33 & 0.15 & 2.4 & 2.1 & 0.49 & 0.49 & 4.8 \\
\hline 25 & 25.0 & 200 & 92 & 25.0 & 7.8 & 60 & 0.19 & 3.4 & 0.43 & 0.37 & 0.16 & 2.4 \\
\hline 26 & 26.0 & 71 & 52 & 7.7 & 7.5 & 38 & 0.07 & 3.6 & 0.60 & 0.46 & 0.27 & 1.7 \\
\hline 27 & 24.5 & 68 & 34 & 6.0 & 7.2 & 27 & 0.06 & 2.0 & 0.95 & 0.30 & 0.29 & 2.6 \\
\hline 30 & 25.5 & 68 & 36 & 6.0 & 7.2 & 27 & 0.01 & 0.02 & 1.5 & 0.51 & 0.77 & 2.6 \\
\hline 33 & 25.3 & 130 & 8.0 & 7.2 & 6.2 & 6.5 & 0.96 & 2.9 & 0.99 & 0.10 & 0.12 & 0.4 \\
\hline
\end{tabular}


Appendix 2: (cont.)

\begin{tabular}{|c|c|c|c|c|c|c|c|c|c|c|c|c|}
\hline $\begin{array}{l}\text { Site } \\
\text { no. }\end{array}$ & $\begin{array}{l}\text { Temp. } \\
\left({ }^{\circ} \mathrm{C}\right)\end{array}$ & $\begin{array}{l}\text { Conductivity } \\
\left(\mu \mathrm{S} \mathrm{cm}{ }^{-1}\right)\end{array}$ & $\begin{array}{l}\text { TSS } \\
\left(\mathrm{mg} \mathrm{l}^{-1}\right)\end{array}$ & $\begin{array}{c}\mathrm{DO} \\
\left(\mathrm{mg} \mathrm{l}^{-1}\right)\end{array}$ & $\mathrm{pH}$ & $\begin{array}{l}\text { Turbidity } \\
\text { (NTU) }\end{array}$ & $\begin{array}{c}\text { TP } \\
\left(\mathrm{mg} \mathrm{l}^{-1}\right)\end{array}$ & $\begin{array}{c}\text { TN } \\
\left(\mathrm{mg} \mathrm{l}^{-1}\right)\end{array}$ & $\begin{array}{l}\text { Area } \\
\left(\mathrm{m}^{2}\right)\end{array}$ & $\begin{array}{c}\text { Mean } \\
\text { velocity } \\
\left(\mathrm{m} \mathrm{s}^{-1}\right)\end{array}$ & $\begin{array}{l}\text { Discharge } \\
\left(\mathrm{m}^{3} \mathrm{~s}^{-1}\right)\end{array}$ & $\begin{array}{l}\text { River } \\
\text { width } \\
(\mathrm{m})\end{array}$ \\
\hline \multicolumn{13}{|c|}{ Kericho-Upper Nyando, December 2005} \\
\hline 1 & 15.4 & 150 & 28 & 56 & 7.3 & 73 & 0.15 & 1.4 & 0.57 & 2.4 & 1.4 & 1.3 \\
\hline 3 & 18.4 & 130 & 79 & 64 & 6.9 & 75 & 0.08 & 2.2 & 0.90 & 0.50 & 0.46 & 1.2 \\
\hline 4 & 18.4 & 130 & 53 & 64 & 7.1 & 89 & 0.08 & 2.3 & 1.2 & 0.63 & 0.76 & 2.6 \\
\hline 5 & 17.5 & 140 & 31 & 74 & 7.5 & 93 & 0.07 & 1.6 & 2.0 & 0.60 & 1.2 & 7.8 \\
\hline 6 & 12.1 & 140 & 29 & 48.0 & 7.5 & 84 & 0.11 & 1.7 & 4.4 & 0.27 & 1.20 & 4.1 \\
\hline 7 & 15.4 & 310 & 53 & 44.0 & 7.8 & 30 & 0.21 & 1.4 & 0.22 & 0.15 & 0.11 & 2.6 \\
\hline 8 & 15.9 & 160 & 62 & 74.0 & 7.4 & 81 & 0.14 & 1.6 & 4.0 & 0.25 & 1.0 & 2.4 \\
\hline 9 & 19.8 & 170 & 31 & 45.0 & 7.5 & 35 & 0.19 & 1.6 & 0.73 & 0.15 & 0.11 & 4.3 \\
\hline 10 & 25.8 & 310 & 88 & 5.7 & 8.1 & 36 & 0.21 & 1.2 & 2.6 & 0.62 & 1.6 & 6.1 \\
\hline 11 & 25.6 & 130 & 38 & 5.2 & 7.1 & 230 & 0.23 & 1.4 & 0.85 & 0.26 & 0.25 & 2.1 \\
\hline 12 & 25.7 & 320 & 64 & 5.9 & 8.2 & 31 & 0.22 & 1.4 & 4.6 & 0.33 & 1.5 & 4.7 \\
\hline 13 & 25.4 & 300 & 97 & 5.2 & 8.0 & 38 & 0.21 & 0.43 & 2.7 & 0.27 & 0.73 & 4.0 \\
\hline 14 & 25.8 & 240 & 160 & 5.4 & 7.8 & 93 & 0.18 & 1.3 & 11.0 & 0.83 & 0.93 & 13.0 \\
\hline \multicolumn{13}{|c|}{ Kericho-Upper Nyando, December 2006} \\
\hline 1 & 14.9 & 160 & 24 & 6.9 & 7.7 & 69 & 0.06 & 1.4 & 0.12 & 0.05 & 0.01 & 3.3 \\
\hline 3 & 19.4 & 130 & 41 & 6.0 & 7.8 & 79 & 0.05 & 2.7 & 0.43 & 0.26 & 0.11 & 2.4 \\
\hline 4 & 17.8 & 130 & 3.3 & 6.0 & 7.7 & 91 & 0.03 & 2.0 & 0.54 & 0.31 & 0.17 & 7.0 \\
\hline 5 & 16.9 & 140 & 14 & 7.6 & 7.5 & 98 & 0.03 & 2.4 & 0.92 & 0.37 & 0.35 & 3.9 \\
\hline 6 & 13.0 & 140 & 0.03 & 5.2 & 7.7 & 79 & 0.03 & 0.20 & 1.1 & 0.32 & 0.36 & 6.9 \\
\hline 7 & 14.8 & 310 & 30 & 5.8 & 8.2 & 34 & 0.10 & 0.79 & 0.10 & 0.03 & 0.004 & 1.2 \\
\hline 8 & 15.0 & 170 & 28 & 8.2 & 8.2 & 89 & 0.05 & 1.4 & 0.95 & 0.28 & 0.27 & 7.8 \\
\hline 9 & 21.3 & 160 & 20 & 5.0 & 8.0 & 29 & 0.05 & 0.44 & 0.53 & 0.18 & 0.12 & 2.5 \\
\hline 10 & 26.1 & 320 & 40 & 6.3 & 7.8 & 41 & 0.14 & 0.73 & 1.7 & 0.41 & 0.42 & 7.9 \\
\hline 11 & 24.6 & 130 & 25 & 6.0 & 8.6 & 220 & 0.25 & 0.83 & 0.32 & 0.10 & 0.03 & 12.0 \\
\hline 12 & 25.3 & 320 & 78 & 6.2 & 8.8 & 36 & 0.26 & 0.69 & 1.6 & 0.19 & 0.31 & 7.9 \\
\hline 13 & 26.0 & 130 & 36 & 4.8 & 8.8 & 40 & 0.25 & 0.53 & 0.77 & 0.09 & 0.08 & 24.0 \\
\hline 14 & 23.9 & 320 & 22 & 6.0 & 8.4 & 89 & 0.14 & 0.95 & 3.9 & 0.34 & 1.4 & 21.0 \\
\hline \multicolumn{13}{|c|}{ Nandi-Lower Nyando, December 2005} \\
\hline 15 & 15.4 & 150 & 28 & 56.0 & 7.3 & 73 & 0.15 & 1.4 & 0.57 & 2.4 & 1.4 & 1.3 \\
\hline 16 & 18.4 & 130 & 79 & 64.0 & 6.9 & 75 & 0.08 & 2.2 & 0.90 & 0.50 & 0.46 & 1.2 \\
\hline 17 & 18.4 & 130 & 53 & 64.0 & 7.1 & 89 & 0.08 & 2.3 & 1.2 & 0.63 & 0.76 & 2.6 \\
\hline 18 & 17.5 & 140 & 31 & 74.0 & 7.5 & 93 & 0.07 & 1.6 & 2.0 & 0.60 & 1.2 & 7.8 \\
\hline 19 & 12.1 & 140 & 29 & 48.0 & 7.5 & 84 & 0.11 & 1.7 & 4.4 & 0.27 & 1.20 & 4.1 \\
\hline 21 & 15.4 & 310 & 53 & 44.0 & 7.8 & 30 & 0.21 & 1.4 & 0.22 & 0.15 & 0.11 & 2.6 \\
\hline 22 & 15.9 & 160 & 62 & 74.0 & 7.4 & 81 & 0.14 & 1.6 & 4.0 & 0.25 & 1.0 & 2.4 \\
\hline 23 & 19.8 & 170 & 31 & 45.0 & 7.5 & 35 & 0.19 & 1.6 & 0.73 & 0.15 & 0.11 & 4.3 \\
\hline 25 & 25.8 & 310 & 88 & 5.7 & 8.1 & 36 & 0.21 & 1.2 & 2.6 & 0.62 & 1.6 & 6.1 \\
\hline 26 & 25.6 & 130 & 38 & 5.2 & 7.1 & 230 & 0.23 & 1.4 & 0.85 & 0.26 & 0.25 & 2.1 \\
\hline 27 & 25.7 & 320 & 64 & 5.9 & 8.2 & 31 & 0.22 & 1.4 & 4.6 & 0.33 & 1.5 & 4.7 \\
\hline 30 & 25.4 & 300 & 97 & 5.2 & 8.0 & 38 & 0.21 & 0.43 & 2.7 & 0.27 & 0.73 & 4.0 \\
\hline 33 & 25.8 & 240 & 160 & 5.4 & 7.8 & 93 & 0.18 & 1.3 & 11.0 & 0.83 & 0.93 & 13.0 \\
\hline \multicolumn{13}{|c|}{ Nandi-Lower Nyando, December 2006} \\
\hline 15 & 17.6 & 310 & 250 & 6.7 & 7.7 & 380 & 0.71 & 2.7 & 7.2 & 0.35 & 2.5 & 43.0 \\
\hline 16 & 20.0 & 250 & 19 & 6.3 & 7.6 & 310 & 0.53 & 2.3 & 12 & 0.16 & 2.0 & 51.0 \\
\hline 17 & 18.6 & 220 & 20 & 6.8 & 7.8 & 310 & 0.32 & 1.6 & 5.0 & 0.40 & 2.0 & 48.0 \\
\hline 18 & 21.0 & 110 & 13 & 4.6 & 7.6 & 270 & 0.12 & 1.2 & 1.3 & 0.05 & 0.07 & 23.0 \\
\hline 19 & 15.9 & 200 & 17 & 6.2 & 8.0 & 130 & 0.11 & 0.53 & 5.0 & 0.44 & 2.2 & 3.9 \\
\hline 21 & 14.0 & 190 & 34 & 7.7 & 8.1 & 100 & 0.15 & 0.25 & 1.5 & 0.12 & 0.19 & 7.8 \\
\hline 22 & 14.8 & 260 & 16 & 6.9 & 8.3 & 68 & 0.09 & 0.60 & 5.1 & 0.08 & 0.41 & 4.9 \\
\hline 23 & 16.1 & 250 & 44 & 6.2 & 8.4 & 48 & 0.09 & 0.90 & 0.52 & 0.36 & 0.19 & 1.9 \\
\hline 25 & 21.0 & 150 & 48 & 6.9 & 8.1 & 49 & 0.11 & 1.6 & 0.40 & 0.22 & 0.09 & 3.0 \\
\hline 26 & 14.8 & 70 & 28 & 7.1 & 7.7 & 42 & 0.09 & 1.6 & 0.76 & 0.59 & 0.45 & 2.3 \\
\hline 27 & 22.0 & 49 & 48 & 4.6 & 7.9 & 21 & 0.11 & 0.99 & 0.63 & 0.23 & 0.15 & 2.1 \\
\hline 30 & 17.3 & 17 & 0.01 & 7.0 & 7.2 & 2.0 & 0.01 & 0.04 & 0.06 & 0.08 & 0.01 & 0.60 \\
\hline 33 & 24.8 & 130 & 14 & 4.0 & 7.8 & 230 & 0.21 & 0.54 & 0.48 & 0.06 & 0.03 & 1.9 \\
\hline
\end{tabular}

